\title{
Palynomorph Biostratigraphy and Paleoecology of Upper Cretaceous Sediments from Four Cores from Screven and Burke Counties, Georgia
}

\author{
By Norman 0. Frederiksen, Lucy E. Edwards, and Ronald J. Litwin
}

\section{U.S. GEOLOGICAL SURVEY PROFESSIONAL PAPER 1603-C}




\section{CONTENTS}

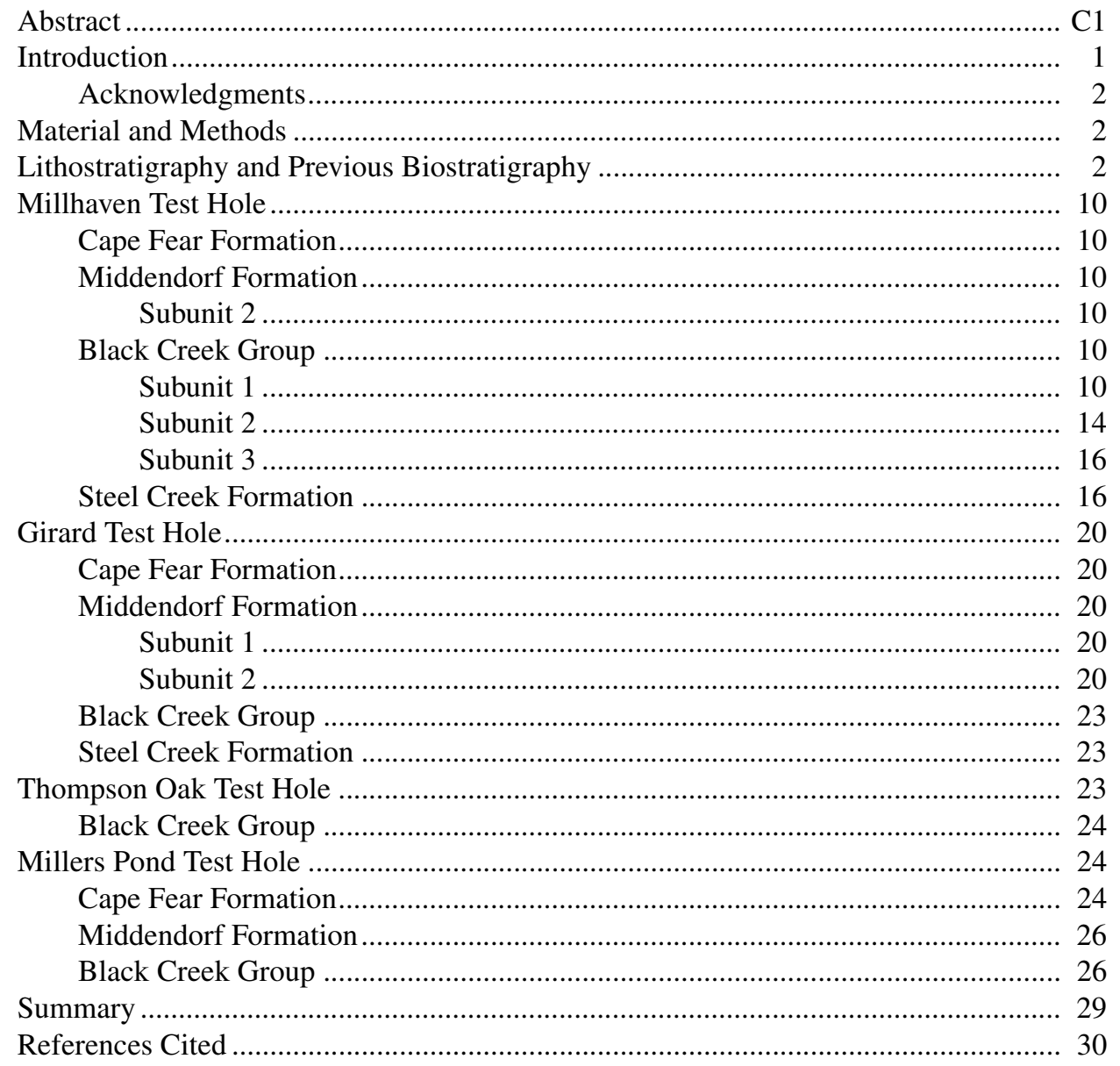

\section{PLATES}

[Plates follow References Cited]

1-5. Pollen.

6. Dinoflagellates and acritarchs.

7. Dinoflagellates.

\section{FIGURES}

1. Index map showing the Savannah River Site and locations of stratigraphic test holes in the study area

2. Chart showing European stage assignments of Coniacian to Maastrichtian formations in New Jersey and the main pollen zonations proposed for these formations

3. Chart showing pollen taxa occurrences in 11 samples between 1,212.0 and $733.2 \mathrm{ft}$ in the Millhaven core, Screven County, Ga. 
4. Chart showing dinoflagellate taxa occurrences in 10 samples between 1,212.0 and $680.8 \mathrm{ft}$ in the Millhaven core, Screven County, Ga.

5-10. Chart showing known stratigraphic ranges of pollen taxa in the Millhaven core, Screven County, Ga.:

5. Sample R4664 CA, subunit 1 of the Black Creek Group, from 1,124.3-1,124.7 ft ..................................... 13

6. Sample R4664 BB, subunit 2 of the Black Creek Group, from 1,029.5 ft ................................................ 14

7. Sample R4664 FD, subunit 2 of the Black Creek Group, from 941.7-941.9 ft.......................................... 15

8. Three samples (R4664 CD, DA, and FE) from the Steel Creek Formation between 830.5 and $824.1 \mathrm{ft} \ldots \ldots \ldots . .17$

9. Sample R4664 GA, Steel Creek Formation, from 769.0-769.3 ft......................................................... 18

10. Sample R4664 CF, Steel Creek Formation, from 733.2-733.3 ft ............................................................. 19

11. Chart showing pollen taxa occurrences in three samples between $1,139.0$ and $738.3 \mathrm{ft}$ in the Girard core, Burke County, Ga.

12. Chart showing dinoflagellate taxa occurrences in 15 samples between $1,139.0$ and $720.3 \mathrm{ft}$ in the Girard core, Burke County, Ga.

13-15. Charts showing known stratigraphic ranges of pollen taxa in the Girard core, Burke County, Ga.:

13. Sample R4705 AA, subunit 1 of the Middendorf Formation, from 1,138.0-1,139.0 ft .............................. 22

14. Sample R4705 BA, subunit 2 of the Middendorf Formation, from 1,012.0-1,012.3 ft................................. 22

15. Sample R4705 BG, subunit 2 of the Black Creek Group, from 738.3-738.6 ft ……............................... 23

16. Chart showing dinoflagellate taxa occurrences in two samples from 561.0 and $505.0 \mathrm{ft}$, respectively

(Black Creek Group), in the Thompson Oak core, Burke County, Ga.

17. Chart showing pollen taxa occurrences in four samples between 832.0 and $517.0 \mathrm{ft}$ in the Millers Pond core, Burke County, Ga.

18-20. Charts showing known stratigraphic ranges of pollen taxa in the Millers Pond core, Burke County, Ga.:

18. Sample R4581 B, Cape Fear Formation, from 827.0-832.0 ft ............................................................. 26

19. Sample R4581 C, Cape Fear Formation, from 797.0-802.0 ft ...................................................... 27

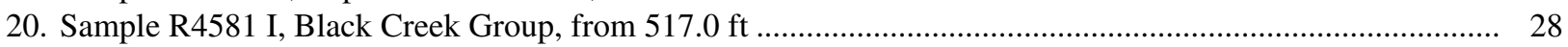

\section{TABLES}

1. Pollen and dinoflagellate occurrences in samples from the Upper Cretaceous units of the Millhaven, Girard, Thompson Oak, and Millers Pond cores, Screven and Burke Counties, Georgia

2. Coordinates of photographed pollen specimens on Leitz microscope 871956 at the U.S. Geological Survey, Reston, Virginia...

3. Coordinates of photographed dinoflagellate and acritarch specimens on Olympus Vanox microscope 201526 at the U.S. Geological Survey, Reston, Virginia.

4. List of pollen taxa mentioned in this paper with some synonyms

5. List of dinoflagellate and acritarch taxa mentioned in this paper... 


\title{
Palynomorph Biostratigraphy and Paleoecology of Upper Cretaceous Sediments from Four Cores from Screven and Burke Counties, Georgia
}

\author{
By Norman O. Frederiksen, Lucy E. Edwards, and Ronald J. Litwin
}

\begin{abstract}
Fifty-two Upper Cretaceous samples were examined for palynomorphs (pollen grains and dinoflagellates) from four cores (Millhaven, Girard, Thompson Oak, and Millers Pond) from Screven and Burke Counties, Georgia. Two pollen-bearing samples from the Cape Fear Formation of the Millers Pond core are both of Coniacian or early Santonian age.

Three pollen-bearing samples were obtained from the overlying Middendorf Formation of the Millhaven and Girard cores; one of them is Coniacian or Santonian, one apparently is latest Santonian(?) or earliest Campanian, and one sample is of uncertain age. Dinoflagellate data indicate that the Middendorf Formation in the Millhaven core represents, at least in part, marginal or very nearshore marine conditions, whereas the Middendorf of the updip Girard core appears to be entirely nonmarine.

Seven samples from the Black Creek Group (overlying the Middendorf Formation) of the Millhaven, Girard, and Millers Pond cores had usable pollen assemblages, and these are mid-Campanian to possibly Maastrichtian. Marine strata, particularly in the middle part of the Black Creek Group in the Millhaven, Girard, and Thompson Oak cores, contain late Campanian dinoflagellates. The Black Creek Group in the Millhaven core represents (in upward sequence) marginal or very nearshore marine conditions (subunit 1) and normal marine to nearshore marine conditions (subunits 2 and 3). The Black Creek in the more updip Girard core represents nonmarine, then nearshore marine, then nonmarine deposition. Two samples from the Black Creek Group in the still more updip Thompson Oak core represent, in ascending order, apparent nonmarine and nearshore marine paleoenvironments, respectively.

Five pollen-bearing samples from the Steel Creek Formation (overlying the Black Creek Group) of the Millhaven
\end{abstract}

core appear to be Maastrichtian in age. One sample from the Steel Creek Formation may have at least marginal-marine dinoflagellates. All Cretaceous samples from the most updip Millers Pond core lack dinoflagellates.

\section{INTRODUCTION}

At the Savannah River Site (SRS) in Aiken, Barnwell, and Allendale Counties, S.C. (fig. 1), various hazardous materials have been manufactured, disposed of, and stored since the early 1950's. The U.S. Geological Survey, in cooperation with the U.S. Department of Energy and the Georgia Geologic Survey of the Georgia Department of Natural Resources, is conducting a study of the subsurface geology, hydrology, and water quality in the vicinity of the SRS with the goal of understanding the present and possible future ground-water flow in the aquifers of the area.

Many test holes have been drilled in Georgia and South Carolina to study the flow of ground water in the SRS region (Aadland, 1992; Harris and others, 1992; Strom and others, 1992; Clarke, 1993; Gellici and Logan, 1993; Clarke and others, 1994, 1996; Clarke and West, 1994; Leeth and others, 1996). The Cretaceous and Cenozoic aquifers are difficult to correlate from area to area because of structural movement and rapid facies changes. Some biostratigraphic research has been completed toward the goal of correlating aquifers between some of the test holes (for example, Prowell, Edwards, and Frederiksen, 1985; Edwards, 1992; Edwards and Clarke, 1992; Edwards and Frederiksen, 1992; Lucas-Clark, 1992; Falls and others, 1993, 1997; Clarke and others, 1994, 1996; Leeth and others, 1996; Edwards and others, 1997), but much biostratigraphic study remains to be done in the region.

Palynomorphs are abundant and well-preserved fossils in some of the Cretaceous subsurface sediments in the SRS 


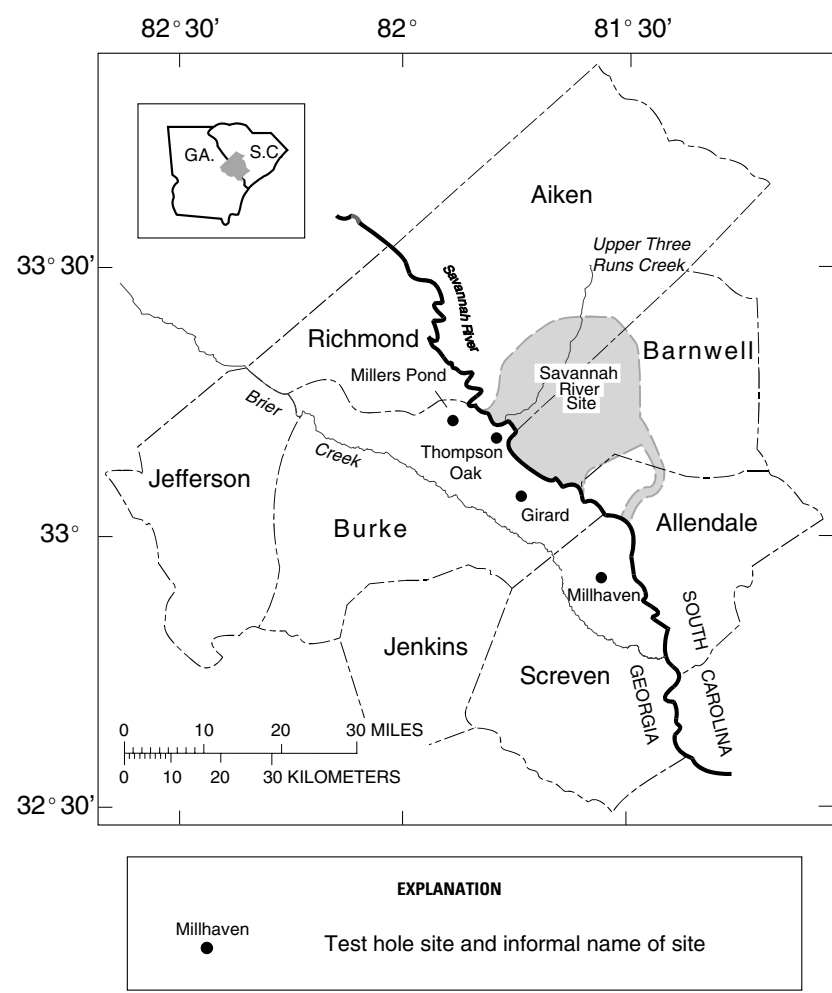

Figure 1. Index map showing the Savannah River Site and locations of stratigraphic test holes in the study area.

region. Palynomorphs include pollen grains and spores from terrestrial plants as well as the cysts—or in a few cases, perhaps thecae —of mainly marine dinoflagellates. The purpose of this paper is to use Cretaceous palynomorphs in core samples to provide biostratigraphic and paleoenvironmental data on both marine and nonmarine sediments in the area. The core samples were taken from four Georgia test holes (Millhaven, Girard, Thompson Oak, Millers Pond) in Screven and Burke Counties, Ga., directly across the Savannah River from the SRS. Table 1 summarizes the number of samples examined from each stratigraphic unit in each test hole.

\section{ACKNOWLEDGMENTS}

We thank U.S. Geological Survey colleagues John S. Clarke, W. Fred Falls, R. Farley Fleming, Gregory S. Gohn, and David C. Prowell, as well as Paul F. Huddlestun (Georgia Geologic Survey, Atlanta) and palynological consultant Joyce Lucas-Clark (Fremont, Calif.) for the sharing of data and ideas and the sometimes lively discussions that helped shape the ideas in this paper. We are grateful to Raymond A. Christopher (Clemson University) and G.S. Gohn for very helpful reviews of the first draft of this paper.

\section{MATERIAL AND METHODS}

The core samples discussed in this paper were cleaned and scraped and then treated in hydrochloric acid and hydrofluoric acid to remove carbonate and silicate material, respectively. Samples were then oxidized in nitric acid and centrifuged in laboratory detergent to remove fine debris. Sample residues were stained in Bismark brown and screened on 8- or 10-micrometer $(\mu \mathrm{m})$ sieves for pollen and on $20-\mu \mathrm{m}$ sieves for dinoflagellates. The residues were swirled in a watch glass and mounted on slides in glycerin jelly for light-microscope observation.

In table 2, which shows the slide numbers and microscope coordinates of photographed pollen specimens, the slide designations show the sample number with the slide number in parentheses. Coordinates locate the specimens on Leitz microscope 871956 at the U.S. Geological Survey, Reston, Va. On this microscope, the coordinates for the center point of a standard $25.4 \times 76.2$-millimeter $(\mathrm{mm})$ slide are 38.8 and 102.5 for the horizontal and vertical axes. The horizontal coordinates increase toward the right edge of the stage, and the vertical coordinates increase toward the front of the stage.

The slide numbers and microscope coordinates of photographed dinoflagellates (table 3) locate the specimens on Olympus Vanox microscope 201526 at the U.S. Geological Survey, Reston, Va. On this microscope, the coordinates for the center point of a standard $25.4 \times 76.2-\mathrm{mm}$ slide are 27.5 and 112.7 for the vertical and horizontal axes. The vertical coordinates increase as the stage is moved up, and the horizontal coordinates increase as the slide is moved from left to right.

All palynological slides are stored at the U.S. Geological Survey, Reston, Va.

\section{LITHOSTRATIGRAPHY AND PREVIOUS BIOSTRATIGRAPHY}

Details of the geologic framework are presented elsewhere (Falls and Prowell, this volume, chap. A). Falls and Prowell recognize three formations and one group within the Cretaceous, and their terminology and correlations are followed here. The Cape Fear Formation is the lowermost unit studied and consists of partially lithified to unlithified, poorly to very poorly sorted clayey sand and sandy clay. It is overlain by the Middendorf Formation, a poorly consolidated, poorly sorted sand that contains thin clay beds; Falls and Prowell (this volume, chap. A) divide the Middendorf into two informal subunits. Above the Middendorf Formation, Falls and Prowell (this volume, chap. A) recognize the Black Creek Group, which they divide into three informal subunits that do not coincide with named formations that have been studied elsewhere. The uppermost Cretaceous 
Table 1. Pollen and dinoflagellate occurrences in samples from the Upper Cretaceous units of the Millhaven, Girard, Thompson Oak, and Millers Pond cores, Screven and Burke Counties, Georgia.

[Sample depths are in feet below land surface. Symbols in the last four columns are defined next.

$\mathrm{P}$ (pollen) column: Y (yes), sample contains pollen that is biostratigraphically useful; $\mathrm{N}$ (no), sample contains pollen that is not biostratigraphically useful; C, sample contains contaminants only; o, pollen was observed in the sample but not studied.

D (dinoflagellate) column: Y (yes), has dinoflagellates; C, has only contaminant dinoflagellates; o, dinoflagellates were observed in the sample but not studied.

B (barren) column: X, sample is barren of all palynomorphs.

ND (no dinoflagellates) column: X, sample was examined for dinoflagellates, but none were found; however, at least some pollen was observed in the sample]

\begin{tabular}{|c|c|c|c|c|c|c|}
\hline $\begin{array}{c}\text { Sample } \\
\mathrm{R} \text { number }\end{array}$ & $\begin{array}{c}\text { Depth } \\
\text { (ft) }\end{array}$ & Unit (subunit) & $\mathrm{P}$ & $\mathrm{D}$ & B & ND \\
\hline \multicolumn{7}{|c|}{ Millhaven core, Screven County, Ga. } \\
\hline R4664 CG----------- & $680.8-681$ & Steel Creek & --- & --- & $\mathrm{X}$ & --- \\
\hline R4664 CF ---------- & $733.2-733.3$ & Steel Creek & $\mathrm{Y}$ & --- & --- & $\mathrm{X}$ \\
\hline R4664 FG ---------- & $755-755.3$ & Steel Creek & $\mathrm{C}$ & $\mathrm{Y} ? \mathrm{C}$ & --- & --- \\
\hline R4664 GB ----------- & $755.3-755.6$ & Steel Creek & $\mathrm{C}$ & $\mathrm{C}$ & --- & --- \\
\hline R4664 CE ----------- & 768.8-769 & Steel Creek & --- & --- & $\mathrm{X}$ & --- \\
\hline R4664 GA---------- & $769.0-769.3$ & Steel Creek & $\mathrm{Y}$ & --- & --- & --- \\
\hline R4664 FF------------ & 789.7-790 & Steel Creek & --- & --- & $\mathrm{X}$ & --- \\
\hline R4664 FE--------- & $824.1-824.4$ & Steel Creek & $\mathrm{Y}$ & --- & --- & $\mathrm{X}$ \\
\hline R4664 DA----------- & $829.5-829.8$ & Steel Creek & $\mathrm{Y}$ & --- & --- & --- \\
\hline R4664 CD----------- & $830.3-830.5$ & Steel Creek & $\mathrm{Y}$ & $\mathrm{Y}$ & --- & --- \\
\hline R4664 CC ----------- & $849.3-849.6$ & Black Creek Group (3) & $\mathrm{N}$ & $\mathrm{Y}$ & --- & --- \\
\hline R4664 CB ---------- & $913.8-914.2$ & Black Creek Group (3) & $\mathrm{Y}$ & $\mathrm{Y}$ & --- & --- \\
\hline R4664 FD ---------- & $941.7-941.9$ & Black Creek Group (2) & $\mathrm{Y}$ & $\mathrm{Y}$ & --- & --- \\
\hline R4664 BB ---------- & 1029.5 & Black Creek Group (2) & $\mathrm{Y}$ & $\mathrm{Y}$ & --- & --- \\
\hline R4664 CA---------- & $1124.3-1124.7$ & Black Creek Group (1) & $\mathrm{Y}$ & $\mathrm{Y}$ & --- & --- \\
\hline R4664 BA ---------- & 1212 & Middendorf (2) & $\mathrm{Y}$ & $\mathrm{Y}$ & --- & --- \\
\hline \multicolumn{7}{|c|}{ Girard core, Burke County, Ga. } \\
\hline R4705 BH----------- & $720.3-720.5$ & Black Creek Group (3) & o & --- & -- & $\mathrm{X}$ \\
\hline R4705 BG----------- & $738.3-738.6$ & Black Creek Group (2) & $\mathrm{Y}$ & $\mathrm{Y}$ & --- & --- \\
\hline R4705 CE ----------- & 784-784.3 & Black Creek Group (2) & o & $\mathrm{Y}$ & --- & --- \\
\hline R4705 CD---------- & $799.7-799.9$ & Black Creek Group (2) & o & o & --- & --- \\
\hline R4705 CC ----------- & $822.8-823$ & Black Creek Group (2) & o & o & --- & --- \\
\hline R4705 CB --------- & $834.6-834.8$ & Black Creek Group (2) & o & $\mathrm{Y}$ & --- & --- \\
\hline R4705 CA---------- & $859.5-859.8$ & Black Creek Group (2) & o & --- & --- & --- \\
\hline R4705 BF ----------- & $868.5-868.7$ & Black Creek Group (2) & o & $\mathrm{Y}$ & --- & --- \\
\hline R4705 BE ---------- & $883.5-883.8$ & Black Creek Group (2) & o & --- & --- & $\mathrm{X}$ \\
\hline R4705 DD----------- & $910-910.5$ & Black Creek Group (1) & o & --- & --- & $\mathrm{X}$ \\
\hline R4705 BD---------- & $924.8-925.2$ & Black Creek Group (1) & o & --- & --- & $\mathrm{X}$ \\
\hline R4705 BC----------- & ca. $960 ?$ & Middendorf (2) & --- & --- & $\mathrm{X}$ & --- \\
\hline R4705 DC----------- & 993.5-994 & Middendorf (2) & --- & --- & $\mathrm{X}$ & --- \\
\hline R4705 BA ----------- & $1012-1012.3$ & Middendorf (2) & $\mathrm{Y}$ & --- & --- & $\mathrm{X}$ \\
\hline R4705 DB ----------- & 1013 & Middendorf (2) & o & --- & --- & $\mathrm{X}$ \\
\hline R4705 AC----------- & $1025.8-1026.2$ & Middendorf (2) & o & --- & --- & $\mathrm{X}$ \\
\hline R4705 DA---------- & 1046.6-1047 & Middendorf (2) & o & --- & --- & $\mathrm{X}$ \\
\hline R4705 AB ---------- & 1063 & Middendorf (1) & --- & --- & $\mathrm{X}$ & --- \\
\hline R4705 AA---------- & $1138-1139$ & Middendorf (1) & $\mathrm{Y}$ & --- & --- & $\mathrm{X}$ \\
\hline \multicolumn{7}{|c|}{ Thompson Oak core, Burke County, Ga. } \\
\hline R4836 B ------------- & 505 & Black Creek Group & o & $\mathrm{Y}$ & --- & --- \\
\hline R4836 A------------- & 561 & Black Creek Group & $\mathrm{o}$ & $\mathrm{Y}$ & --- & --- \\
\hline \multicolumn{7}{|c|}{ Millers Pond core, Burke County, Ga. } \\
\hline R4581 O-------------י- & $282-287$ & Steel Creek & --- & --- & $\mathrm{X}$ & --- \\
\hline R4581 N---------- & 332-337 & Black Creek Group & --- & --- & $\mathrm{X}$ & --- \\
\hline R4581 M ----------- & $397-402$ & Black Creek Group & --- & --- & $\mathrm{X}$ & --- \\
\hline R4581 L ---------- & $447-453$ & Black Creek Group & --- & --- & $\mathrm{X}$ & --- \\
\hline R4581 K------------ & 481 & Black Creek Group & --- & --- & $\mathrm{X}$ & --- \\
\hline R4581 J-------------- & 497.5 & Black Creek Group & --- & --- & $\mathrm{X}$ & --- \\
\hline R4581 I ------------- & 517 & Black Creek Group & $\mathrm{Y}$ & --- & --- & --- \\
\hline R4581 H------------- & $557.5-558$ & Black Creek Group & $\mathrm{N}$ & --- & --- & --- \\
\hline R4581 G ----------- & 578 & Black Creek Group & $\mathrm{Y}$ & --- & --- & --- \\
\hline R4581 F ----------- & 608 & Middendorf & --- & --- & $\mathrm{X}$ & --- \\
\hline 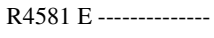 & $662-671$ & Middendorf & --- & --- & $\mathrm{X}$ & --- \\
\hline R4581 D------------- & 778 & Cape Fear & --- & --- & $\mathrm{X}$ & --- \\
\hline R4581 C ---------- & 797-802 & Cape Fear & $\mathrm{Y}$ & --- & --- & --- \\
\hline R4581 B ----------- & $827-832$ & Cape Fear & $\mathrm{Y}$ & --- & --- & --- \\
\hline R4581 A------------ & $847-852$ & Cape Fear & --- & --- & $\mathrm{X}$ & --- \\
\hline
\end{tabular}


Table 2. Coordinates of photographed pollen specimens on Leitz microscope 871956 at the U.S. Geological Survey, Reston, Virginia.

\begin{tabular}{|c|c|c|}
\hline Figure & Sample R no. (slide no.) & Coordinates \\
\hline \multicolumn{3}{|c|}{ Plate 1} \\
\hline 1 -------------------- & R4705 AA(5) & $60.6 \times 94.9$ \\
\hline 2 ---------------------- & R4664 DA(3) & $56.3 \times 103.0$ \\
\hline 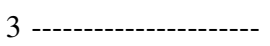 & R4664 FE(1) & $55.5 \times 103.0$ \\
\hline 4 ----------------------- & R4581 I(5) & $55.2 \times 108.0$ \\
\hline 5 --------------------- & R4664 FE(1) & $50.1 \times 105.2$ \\
\hline $6,7--$ & R4664 DA(3) & $32.1 \times 109.9$ \\
\hline $8----$ & $\mathrm{R} 4664 \mathrm{CD}(4)$ & $65.3 \times 100.3$ \\
\hline 9 ---------------------- & R4664 DA(3) & $56.5 \times 112.1$ \\
\hline 10 -------- & R4664 FE(1) & $58.6 \times 110.3$ \\
\hline 11 --------------------- & R4664 DA(3) & $54.0 \times 107.8$ \\
\hline $12---$ & R4664 FE(1) & $60.6 \times 95.7$ \\
\hline 13 --------------------- & R4705 BG(4) & $50.2 \times 99.4$ \\
\hline 14 -------- & R4664 FD(1) & $59.5 \times 96.4$ \\
\hline 15,16 & R4664 DA(3) & $54.8 \times 101.7$ \\
\hline $17----$ & R4664 GA(1) & $55.1 \times 102.1$ \\
\hline 18 ----------- & $\mathrm{R} 4664 \mathrm{CA}(6)$ & $54.8 \times 99.8$ \\
\hline 19-21 ----------- & R4664 GA(1) & $62.3 \times 105.1$ \\
\hline \multicolumn{3}{|c|}{ Plate 2} \\
\hline 1 ---------------------- & R4664 FD(1) & $49.9 \times 110.3$ \\
\hline $2-----$ & R4664 DA(3) & $52.7 \times 95.8$ \\
\hline $3,4--$ & R4664 FD(1) & $52.2 \times 105.8$ \\
\hline - & $\mathrm{R} 4581 \mathrm{I}(5)$ & $56.5 \times 111.5$ \\
\hline 6, 7 --------------- & R4664 GA(1) & $57.2 \times 99.0$ \\
\hline 8 -------------------- & R4581 C(1) & $56.5 \times 95.2$ \\
\hline 9 ---------------------- & R4581 C(1) & $60.5 \times 95.3$ \\
\hline 10 ------. & $\mathrm{R} 4581 \mathrm{~B}(1)$ & $45.9 \times 97.3$ \\
\hline 11 --------------------- & R4705 BA(4) & $50.2 \times 106.2$ \\
\hline 12 --------- & R4581 C(1) & $57.0 \times 94.2$ \\
\hline 13 --------. & R4581 C(1) & $54.6 \times 99.1$ \\
\hline 14 --------------------- & R4664 CA(6) & $64.1 \times 104.4$ \\
\hline 15 -------------------- & R4581 B(1) & $52.5 \times 95.2$ \\
\hline 16 --------------------- & R4664 FD(1) & $51.2 \times 107.4$ \\
\hline 17-19 ------------- & R4581 B(1) & $56.3 \times 97.3$ \\
\hline 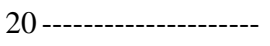 & R4664 CA(6) & $42.8 \times 93.3$ \\
\hline 21 --------------------- & R4581 C(1) & $58.5 \times 102.6$ \\
\hline
\end{tabular}

\begin{tabular}{|c|c|c|}
\hline Figure & Sample R no. (slide no.) & Coordinates \\
\hline \multicolumn{3}{|c|}{ Plate 3} \\
\hline 1------০-------------- & R4705 AA(5) & $58.0 \times 96.8$ \\
\hline 2------- & R4664 CA(6) & $53.7 \times 102.5$ \\
\hline 3------- & R4664 CA(6) & $60.4 \times 94.7$ \\
\hline $4,5-----$ & R4664 CA(6) & $66.4 \times 101.6$ \\
\hline 6, 7----- & R4581 C(1) & $51.8 \times 102.6$ \\
\hline 8-------. & R4581 C(1) & $54.6 \times 102.3$ \\
\hline 9---------- & R4581 I(5) & $61.4 \times 101.9$ \\
\hline 10, 11---------------' & R4581 I(5) & $58.0 \times 99.2$ \\
\hline $12---\cdot$ & R4664 GA(1) & $56.2 \times 111.0$ \\
\hline 13 ----- & R4664 GA(1) & $54.0 \times 101.2$ \\
\hline $14,15--$ & R4705 BG(4) & $62.1 \times 94.8$ \\
\hline $16-----$ & R4664 GA(1) & $51.8 \times 108.4$ \\
\hline \multicolumn{3}{|c|}{ Plate 4} \\
\hline 1, 2------------------- & R4664 DA(3) & $33.3 \times 101.2$ \\
\hline 3----- & R4581 I(5) & $59.6 \times 106.6$ \\
\hline 4------- & $\mathrm{R} 4705 \mathrm{BA}(4)$ & $58.3 \times 94.6$ \\
\hline 5----- & R4705 BA(4) & $60.6 \times 100.9$ \\
\hline 6----- & R4581 C(1) & $56.7 \times 103.0$ \\
\hline 7----- & R4664 GA(1) & $53.0 \times 93.8$ \\
\hline 8----- & $\mathrm{R} 4705 \mathrm{AA}(5)$ & $61.9 \times 107.6$ \\
\hline 9------ & R4705 BA(4) & $60.0 \times 102.4$ \\
\hline $10,11--$ & R4705 BA(4) & $39.9 \times 111.6$ \\
\hline $12,13--$ & R4705 AA(5) & $49.6 \times 97.3$ \\
\hline 14, 15----- & R4664 DA(3) & $34.8 \times 105.8$ \\
\hline \multicolumn{3}{|c|}{ Plate 5} \\
\hline 1----------------------- & R4705 BG(4) & $52.4 \times 103.1$ \\
\hline ------------- & R4664 BB(5) & $54.8 \times 98.3$ \\
\hline 3------- & R4664 BB(5) & $57.5 \times 111.4$ \\
\hline 4, 5--------. & R4705 BG(4) & $61.2 \times 110.5$ \\
\hline 6, 7------- & R4705 AA(5) & $60.5 \times 97.8$ \\
\hline 8, 9------------------- & R4664 FE(1) & $58.5 \times 98.7$ \\
\hline 10, 11 ---------------- & R4664 CD(4) & $50.3 \times 107.7$ \\
\hline 12, 13--------------- & R4664 CD(4) & $55.7 \times 112.1$ \\
\hline 14 ----------------------- & R4705 BA(4) & $38.7 \times 99.5$ \\
\hline
\end{tabular}

unit, where present, is the Steel Creek Formation, a poorly sorted sand and clay.

In this paper, age determinations for samples from the Upper Cretaceous of Georgia are made using pollen and dinoflagellate taxa. The chronostratigraphic ranges of these fossils are known on the basis of previous work mainly in the Middle Atlantic States. European stage assignments and ages of Upper Cretaceous formations in New Jersey (fig. 2) are based primarily on calcareous nannofossil correlations, but the relation between calcareous nannofossil zones and European stages is subject to revision. Here, we use the boundary proposals summarized by Burnett (1996) from the Second Symposium on Cretaceous Stage Boundaries, Brussels, 1995.

Of particular importance to our work is the placement of the Campanian-Maastrichtian boundary at the first appearance datum of the ammonite Pachydiscus neubergicus (von Hauer) in the Teras Quarry, France. This boundary position is stratigraphically higher (younger) than some previous interpretations of the boundary. When this boundary is correlated using nannofossil and foraminiferal zones, some strata that were previously considered to be Maastrichtian should now be considered to be upper Campanian. For example, the Mount Laurel Formation of New Jersey was considered by some earlier authors (for example, Olsson and others, 1988; Aurisano, 1989) to be lower Maastrichtian. However, the Mount Laurel Formation has been assigned to calcareous nannofossil Zone CC 22 (Self-Trail and Bybell, 1995; Sugarman and others, 1995), and Burnett 
Table 3. Coordinates of photographed dinoflagellate and acritarch specimens on Olympus Vanox microscope 201526 at the U.S. Geological Survey, Reston, Virginia.

\begin{tabular}{|c|c|c|}
\hline Figure & Sample R no. (slide no.) & Coordinates \\
\hline \multicolumn{3}{|c|}{ Plate 6} \\
\hline 1 ------------------ & R4705 BG(3) & $32.8 \times 100.0$ \\
\hline 2 ------------------ & R4664 BB(4) & $30.1 \times 97.8$ \\
\hline 3 ---------------- & R4705 BF(3) & $35.5 \times 86.9$ \\
\hline 4 ------------------ & R4664 BB(4) & $26.4 \times 96.1$ \\
\hline 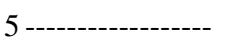 & R4664 CB(3) & $37.0 \times 83.5$ \\
\hline 6 ------------------ & R4705 BF(2) & $32.5 \times 99.2$ \\
\hline 7 ------------------ & R4705 BG(3) & $29.2 \times 72.0$ \\
\hline 8 ----------------- & R4664 BB(4) & $24.2 \times 99.7$ \\
\hline 9 -------------------- & R4664 BB(4) & $24.4 \times 77.5$ \\
\hline 10---------------- & R4664 CB(4) & $20.3 \times 105.2$ \\
\hline 11------------------ & R4705 BG(3) & $37.1 \times 101.5$ \\
\hline 12---------------- & $\mathrm{R} 4705 \mathrm{BF}(2)$ & $25.6 \times 90.8$ \\
\hline 13----------------- & $\mathrm{R} 4705 \mathrm{BF}(2)$ & $34.4 \times 69.6$ \\
\hline 14----------------- & R4664 CB(3) & $34.8 \times 95.9$ \\
\hline 15----------------- & $\mathrm{R} 4705 \mathrm{BF}(2)$ & $20.0 \times 105.3$ \\
\hline 16----------------- & R4705 BG(3) & $31.7 \times 108.9$ \\
\hline \multicolumn{3}{|c|}{ Plate 7} \\
\hline 1 -------------------- & R4705 BF(2) & $32.5 \times 84.4$ \\
\hline 2 ---------------- & R4664 BA(4) & $37.1 \times 73.6$ \\
\hline
\end{tabular}

\begin{tabular}{|c|c|c|}
\hline Figure & Sample R no. (slide no.) & Coordinates \\
\hline \multicolumn{3}{|c|}{ Plate 7-Continued } \\
\hline 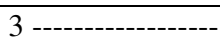 & $\mathrm{R} 4664 \mathrm{BA}(4)$ & $26.7 \times 84.3$ \\
\hline 4 ------ & R4664 BA(4) & $30.7 \times 94.2$ \\
\hline 5 ----------------- & R4664 BB(4) & $23.3 \times 99.6$ \\
\hline 6 ------------------ & R4705 CB(4) & $33.3 \times 80.2$ \\
\hline 7 --------------- & R4664 CD(3) & $22.3 \times 106.7$ \\
\hline 8,9 --- & $\mathrm{R} 4705 \mathrm{CB}(4)$ & $30.2 \times 89.0$ \\
\hline $10---$ & R4664 CA(4) & $36.8 \times 76.4$ \\
\hline $11---$ & R4664 BB(4) & $36.0 \times 108.0$ \\
\hline 12---------------- & $\mathrm{R} 4705 \mathrm{BF}(2)$ & $26.1 \times 72.0$ \\
\hline $13----$ & R4705 BG(3) & $30.1 \times 72.1$ \\
\hline 14-------------- & R4705 BG(3) & $36.0 \times 103.7$ \\
\hline 15---------------- & R4664 CA(4) & $35.8 \times 102.0$ \\
\hline $16---$ & R4664 CA(4) & $32.3 \times 73.7$ \\
\hline $17----$ & R4664 CB(3) & $32.7 \times 100.5$ \\
\hline 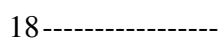 & R4664 BB(4) & $28.7 \times 95.9$ \\
\hline 19--------------- & R4836 B(3) & $30.3 \times 77.4$ \\
\hline 20----------------- & R4664 BB(4) & $28.7 \times 97.8$ \\
\hline 21 ---------------- & R4705 CB(4) & $32.2 \times 81.4$ \\
\hline
\end{tabular}

(1996) placed the Campanian-Maastrichtian boundary within the lower part of Zone CC 23; therefore, we agree with Self-Trail and Bybell (1995) and Sugarman and others (1995) in assigning the Mount Laurel Formation to the upper Campanian (fig. 2).

Sugarman and others (1995) provided nannofossil zonal assignments for the Navesink Formation and for the lower part of the Red Bank Sand of New Jersey. Self-Trail and Bybell (1995) gave nannofossil zonal assignments for the Merchantville, Englishtown, Marshalltown, Mount Laurel, and Navesink Formations. Self-Trail and Bybell presented these stage assignments in terms of Perch-Nielsen's (1985) calcareous nannofossil zonation, but Self-Trail (written commun., 1996) has translated her zonal assignments into the zonal and stage scheme of Burnett (1996), which is followed here.

European stage assignments of Upper Cretaceous formations in the Gulf Coast were summarized by Sohl and others (1991) on the basis mainly of mollusk, planktonic foraminiferal, and calcareous nannofossil data. Tschudy (1973, 1975) and Christopher (1982b,c) instead used pollen taxa to correlate these Gulf Coast stratigraphic units with those of the Atlantic Coastal Plain and of Europe.

The standard pollen zonation for the Upper Cretaceous of the Gulf and Atlantic Coastal Plains (fig. 2) has been developed in a series of abstracts and papers, notably those of Doyle (1969), Sirkin (1974), Wolfe (1976), Doyle and Robbins (1977), and Christopher (1977b, 1982c). This zonation was based on material mainly from the Middle

Atlantic States. The base of pollen Zone V (fig. 2) occurs in the lowermost part of the Austin Chalk of Texas (Christopher, 1982c), which is Coniacian (Sohl and others, 1991). The top of Zone V is Santonian (Christopher and others, 1997). The South Amboy Fire Clay Member, which forms the upper part of the Raritan Formation in New Jersey, has not been dated by means of marine fossils; therefore, the age determinations of Christopher (1977a), as modified by Christopher (1982c), are used for this member. Aurisano's (1989) suggestion that the South Amboy Fire Clay Member should be reassigned from the Raritan to the Magothy Formation appears to be a good idea, but for purposes of the present paper, the South Amboy Fire Clay Member is retained in the Raritan Formation.

In this paper, age determinations are based on pollen range charts presented by Tschudy (1973, 1975), Wolfe (1976), Christopher (1978, 1979), Frederiksen and Christopher (1978), and Litwin and others (1993), with some occurrence and range data from additional publications (for example, Tschudy, 1970; Christopher and others, 1979; Christopher, 1980). We have preferred to use the better known Atlantic Coastal Plain stratigraphic ranges rather than Gulf Coast ranges. However, it appears that some pollen taxa have somewhat different stratigraphic ranges in the Carolinas and Georgia than they have in the Middle Atlantic States. This regional difference may account for difficulties in making age determinations for some samples in this paper (R.A. Christopher, written commun., 1996). Similar 


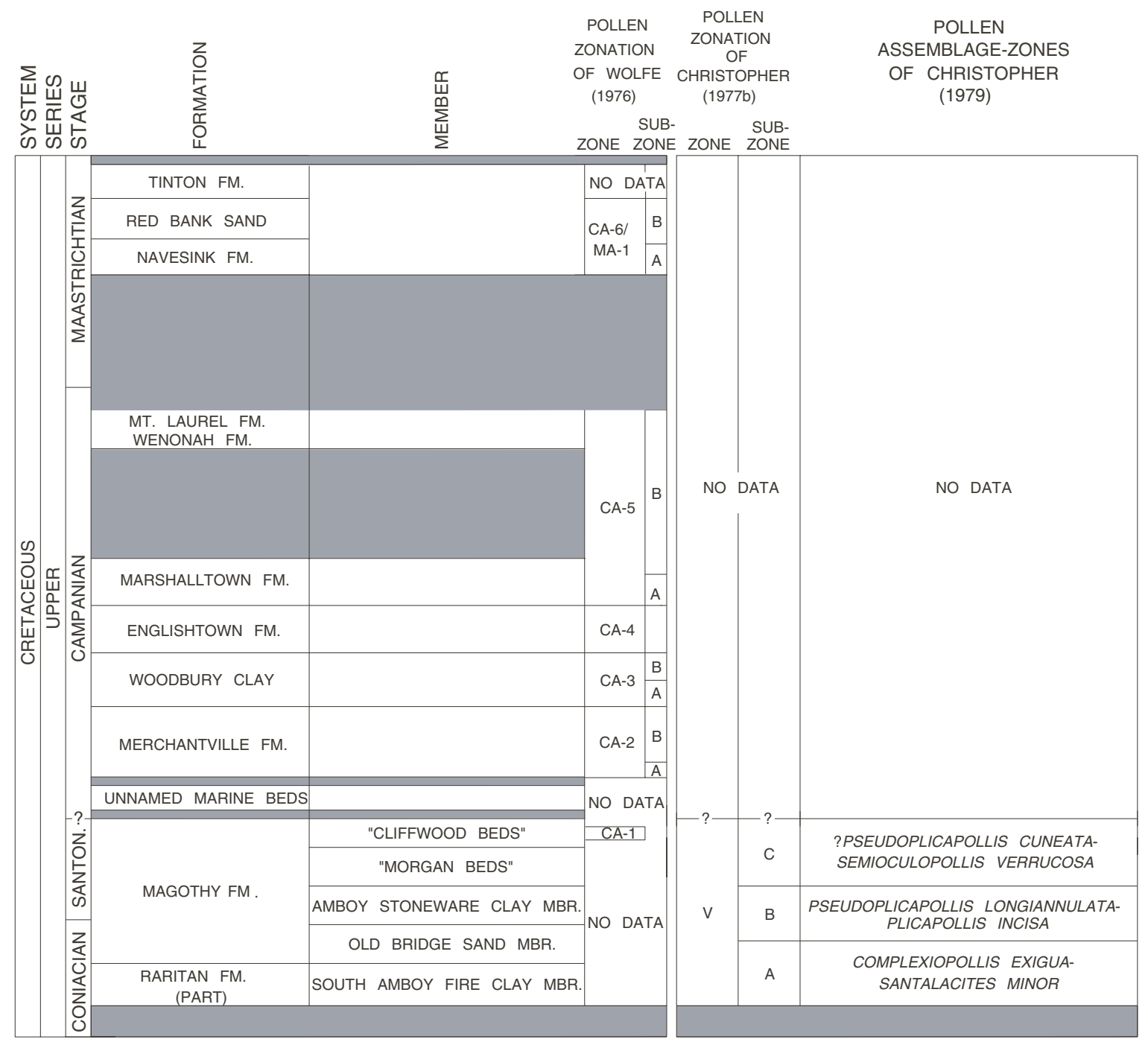

Figure 2. Chart showing European stage assignments of Coniacian to Maastrichtian formations in New Jersey and the main pollen zonations proposed for these formations. Sources of the stage assignments are given in the text. Not shown is the tentative assignment of the unnamed marine beds to Zone CA-2A by Litwin and others (1993). FM., Formation, MBR., Member.

from South Carolina from the same stratigraphic units that are present in the Georgia cores discussed here. The study by Firth (1987) in western Georgia dealt with dinoflagellates near the Cretaceous-Tertiary boundary.

Dinoflagellates from the Atlantic Coastal Plain have been described by several authors, including Koch and Olsson (1977), Whitney (1979), May (1980), and Aurisano (1989). The dinoflagellate succession described by May (1980) from the Mount Laurel Formation in the Atlantic Highlands in New Jersey is of particular relevance. Some of the key dinoflagellate taxa from the present samples are illustrated in plates 6 and 7, and the dinoflagellate and acritarch taxa mentioned in this report are listed in table 5 . 
Table 4. List of pollen taxa mentioned in this paper with some synonyms.

\begin{tabular}{|c|c|c|}
\hline Taxon & Plate & Figure \\
\hline 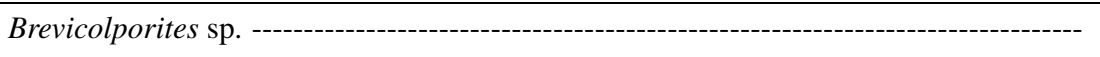 & 3 & 14,15 \\
\hline Brevicolporites sp. A of Christopher (1978); see CP3F-1 --- & - & - \\
\hline $\begin{array}{l}\text { Casuarinidites sp. A of Frederiksen and Christopher (1978) = Triatriopollenites ruren- } \\
\text { sis Pflug \& Thomson in Thomson and Pflug (1953) of Gray and Groot (1966) ----- }\end{array}$ & 1 & 14,17 \\
\hline 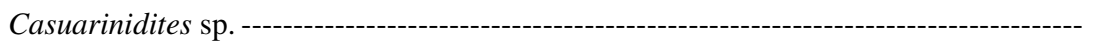 & - & - \\
\hline Complexiopollis abditus Tschudy = NB-1 of Wolfe (1976)---- & 2 & 11 \\
\hline 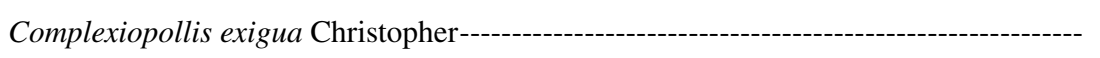 & - & - \\
\hline 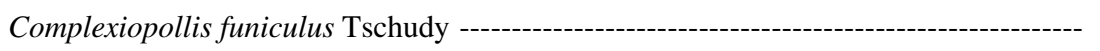 & 2 & 10 \\
\hline Complexiopollis sp. D of Christopher (1979) - & - & - \\
\hline Complexiopollis sp. E of Christopher (1979)--1- & - & - \\
\hline Complexiopollis sp. H of Christopher (1979) --- & - & - \\
\hline 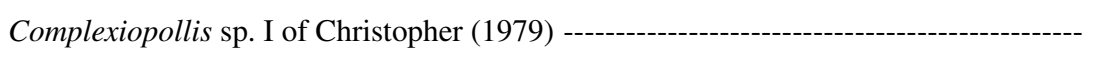 & - & - \\
\hline Complexiopollis sp. ----1--- & 2 & 12 \\
\hline 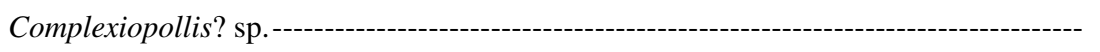 & 2 & $17-19$ \\
\hline C3A-2 of Wolfe (1976) - & - & - \\
\hline Aff. C3C-1 of Wolfe (1976) --1 & 4 & 7 \\
\hline 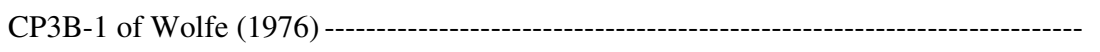 & - & - \\
\hline CP3B-6 of Wolfe (1976) - & - & - \\
\hline CP3D-1 of Wolfe (1976) - & - & - \\
\hline $\begin{array}{l}\text { CP3D-3 of Wolfe }(1976)=\text { Holkopollenites } \text { cf. H. chemardensis Fairchild in Stover and } \\
\text { others (1966) of Christopher (1978)- }\end{array}$ & $\begin{array}{l}4 \\
5\end{array}$ & $\begin{array}{l}3 \\
1-3\end{array}$ \\
\hline CP3E-1 of Wolfe $(1976)=$ ?Holkopollenites sp. of Christopher (1978) ------- & $\begin{array}{l}4 \\
5\end{array}$ & $\begin{array}{l}12,13 \\
4-9\end{array}$ \\
\hline CP3F-1 of Wolfe (1976) in part = Brevicolporites sp. A of Christopher (1978) ------- & $\begin{array}{l}3 \\
4 \\
4\end{array}$ & $\begin{array}{l}12,13 \\
1,2 \\
4,5\end{array}$ \\
\hline CP3F-2 of Wolfe $(1976)=$ Brevicolporites sp. B of Christopher (1978)-- & - & - \\
\hline CP3G-1 of Wolfe (1976) - & 4 & 8 \\
\hline 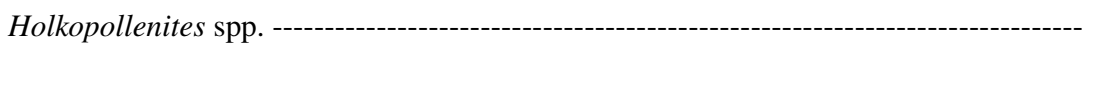 & $\begin{array}{l}4 \\
5\end{array}$ & $\begin{array}{l}14,15 \\
14\end{array}$ \\
\hline 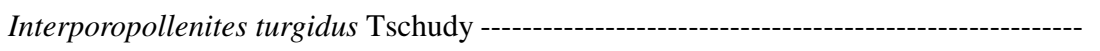 & 2 & 2 \\
\hline Labrapollis sp. B of Christopher (1979) --- & - & - \\
\hline $\begin{array}{l}\text { Lanagiopollis cribellatus } \text { (Srivastava) Frederiksen = CP3A-3 of Wolfe }(1976)=\text { Tri- } \\
\text { colporites } \mathrm{sp} . \mathrm{C} \text { of Christopher (1980) }\end{array}$ & 3 & 16 \\
\hline 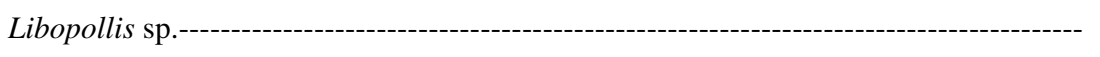 & - & - \\
\hline Momipites fragilis Frederiksen \& Christopher --- & - & - \\
\hline Momipites microfoveolatus (Stanley) Nichols = NK-3 of Wolfe (1976) --- & 1 & 3 \\
\hline $\begin{array}{l}\text { Momipites tenuipolus group of Frederiksen and Christopher (1978) = NK-2 of Wolfe } \\
\text { (1976) }\end{array}$ & 1 & 5 \\
\hline 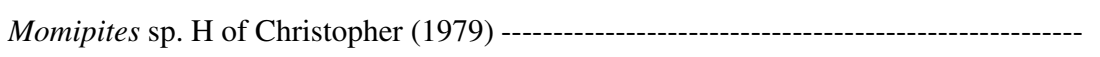 & - & - \\
\hline Momipites sp. I of Christopher (1979) - & - & - \\
\hline 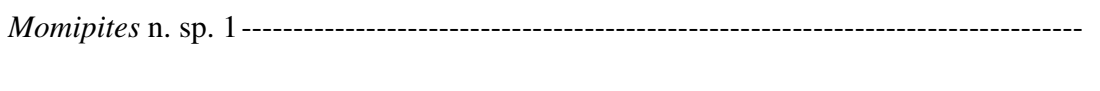 & $\begin{array}{l}1 \\
1\end{array}$ & $\begin{array}{l}6,7 \\
10-12\end{array}$ \\
\hline Cf. MPH-1 of Wolfe (1976) - & 5 & 10,11 \\
\hline New genus A of Tschudy (1975)-- & 2 & 13 \\
\hline New genus D, sp. B of Christopher (1979) --- & 2 & 21 \\
\hline
\end{tabular}


Table 4. List of pollen taxa mentioned in this paper with some synonyms-Continued.

\begin{tabular}{|c|c|c|}
\hline Taxon & Plate & Figure \\
\hline 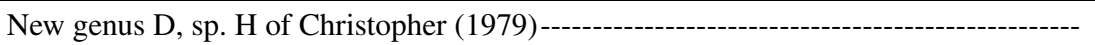 & 2 & 20 \\
\hline New genus D, sp. J of Christopher (1979) - & 3 & 1 \\
\hline 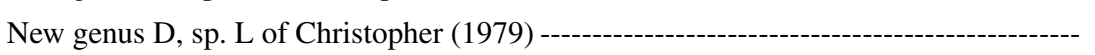 & 3 & 2 \\
\hline N20-2 of R.A. Christopher (unpublished) -- & 3 & $3-5$ \\
\hline N20-12 of R.A. Christopher (unpublished)-- & 1 & 13 \\
\hline NB-2 of Wolfe $(1976)=$ Complexiopollis sp. of Christopher (1978) -- & - & - \\
\hline NB-3 of Wolfe (1976) -- & - & - \\
\hline Cf. ND-2 of Wolfe (1976) - & 2 & 16 \\
\hline NF-1 of Wolfe (1976) = Trudopollis sp. A of Christopher (1978) -- & - & - \\
\hline NO-3 of Wolfe $(1976)=$ Betulaceoipollenites sp. of Christopher (1978) ------- & - & - \\
\hline NP-1 of Wolfe $(1976)=$ Triatriopollenites sp. A of Christopher (1980)----------- & - & - \\
\hline $\begin{array}{l}\text { NP-2 of Wolfe }(1976)=\text { Triatriopollenites sp. of Christopher }(1978)=\text { Triatriopolleni- } \\
\text { tes sp. B of Christopher (1980) }\end{array}$ & 1 & 8,9 \\
\hline 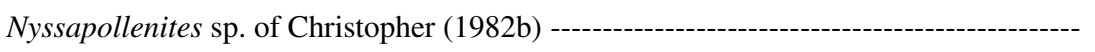 & - & - \\
\hline 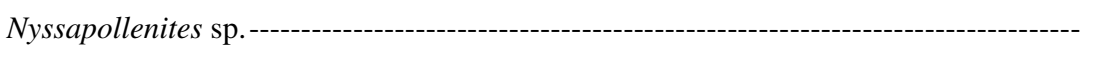 & 4 & 10,11 \\
\hline 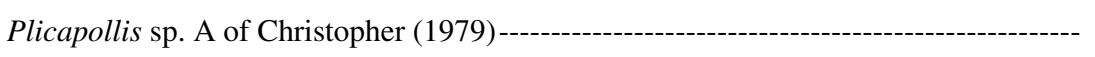 & 2 & 8 \\
\hline 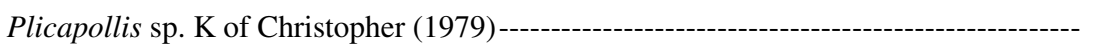 & 2 & 9 \\
\hline Plicatopollis cretacea Frederiksen \& Christopher = NN-2 of Wolfe (1976) ------- & - & - \\
\hline ?Porocolpopollenites sp. A of Christopher and others (1979) ---------------------- & 3 & 6,7 \\
\hline 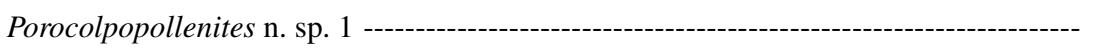 & 3 & 8 \\
\hline 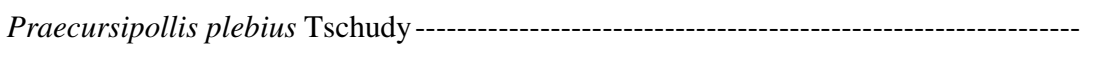 & 2 & 14,15 \\
\hline Proteacidites sp. aff. PR-3 of Wolfe (1976) - & - & - \\
\hline PR-1 of Wolfe (1976) = Proteacidites sp. B of Christopher (1978) ----- & $\begin{array}{l}1 \\
2\end{array}$ & $\begin{array}{l}18 \\
1\end{array}$ \\
\hline PR-5 of Wolfe (1976) = Proteacidites sp. C of Christopher (1978) - & - & - \\
\hline $\begin{array}{l}\text { PR-7 of Wolfe }(1976)=\text { Proteacidites } \mathrm{sp} . \text { A of Christopher }(1978)=\text { Proteacidites } \mathrm{sp} \text {. } \\
\text { G of Christopher }(1980) \text { - }\end{array}$ & 1 & 15,16 \\
\hline 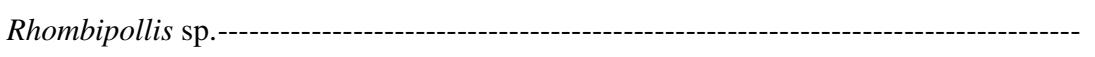 & 3 & 10,11 \\
\hline Rugubivesiculites sp. -- & 1 & 1 \\
\hline Santalacites minor Christopher -- & - & - \\
\hline Tetracolporate sp. ------------------------------ & 5 & 12,13 \\
\hline Triatriopollenites spp. ----------------------- & 1 & 2,4 \\
\hline Tricolpites spp. --- & 2 & $5-7$ \\
\hline Tricolporites sp. ------------------------------ & 4 & 6,9 \\
\hline 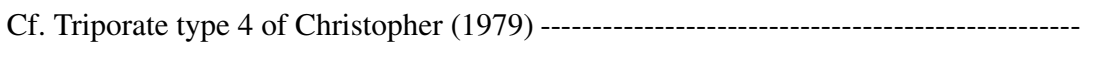 & 1 & $19-21$ \\
\hline Trisectoris costatus Tschudy - & 2 & 3,4 \\
\hline 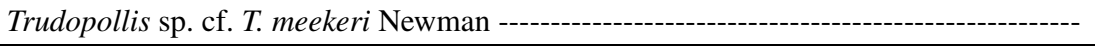 & 3 & 9 \\
\hline
\end{tabular}


Table 5. List of dinoflagellate and acritarch taxa mentioned in this paper.

\begin{tabular}{|c|c|c|}
\hline Taxon & Plate & Figure \\
\hline $\begin{array}{l}\text { Alisogymnium-Dinogymnium spp. }=\text { specimens representing various species of the genera } \\
\text { Alisogymnium Lentin \& Vozzhennikova } 1990 \text { and Dinogymnium Evitt et al. } 1967 \text {----- }\end{array}$ & 6 & 1,2 \\
\hline Alterbidinium acutulum (Wilson 1967) Lentin \& Williams 1985 ------------------------ & 6 & 3 \\
\hline Andalusiella polymorpha (Malloy 1972) Lentin \& Williams 1977 -------------------- & 6 & 5 \\
\hline Andalusiella spicata (May 1980) Lentin \& Williams 1981 -------- & 6 & 4,6 \\
\hline Cerodinium pannuceum (Stanley 1965) Lentin \& Williams 1987 ------------------------ & 6 & 7 \\
\hline 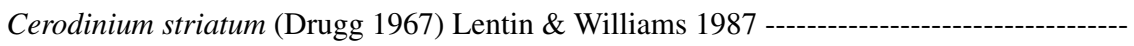 & 6 & 8 \\
\hline Cordosphaeridium fibrospinosum Davey \& Williams 1966 -------------------------- & 6 & 9 \\
\hline Cribroperidinium Neal \& Sarjeant 1962, emend. Helenes 1984 sp.-------- & 6 & 10 \\
\hline 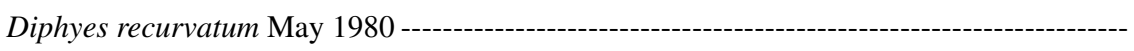 & 6 & 11 \\
\hline 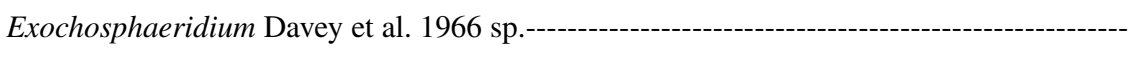 & 6 & 12 \\
\hline 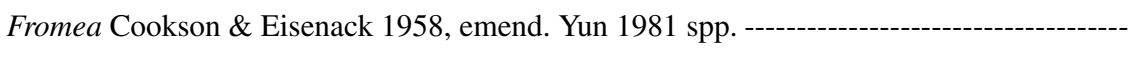 & 6 & 13,14 \\
\hline Lejeunecysta Artzner \& Dorhofer 1978, emend. Bujak 1980 sp. - & 7 & 18 \\
\hline 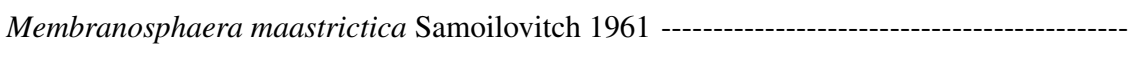 & 6 & 15 \\
\hline Odontochitina costata Alberti 1961 -- & 7 & 1 \\
\hline 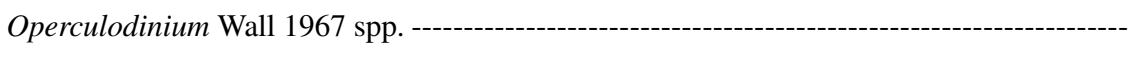 & 6 & 16 \\
\hline 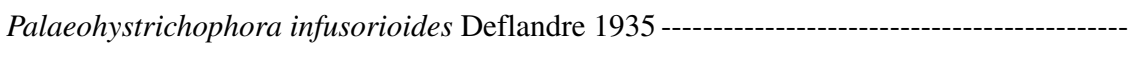 & 7 & 2,3 \\
\hline Palaeoperidinium Deflandre 1934, emend. Sarjeant 1967 sp.-------- & 7 & 4 \\
\hline 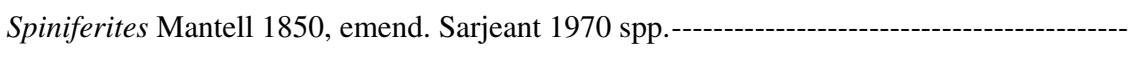 & 7 & 6 \\
\hline Spongodinium delitiense (Ehrenberg 1838) Deflandre 1936 --------- & 7 & 7 \\
\hline Tanyosphaeridium xanthiopyxides (Wetzel 1933) Stover \& Evitt 1978 --------------- & 7 & 5 \\
\hline Tricodinium castanea (Deflandre 1935) Clark \& Verdier 1967 ----------- & 7 & 8,9 \\
\hline Xenascus ceratioides (Deflandre 1937) Lentin \& Williams 1973 ---------- & 7 & 19 \\
\hline 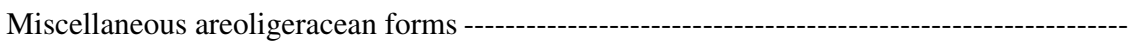 & 7 & $15-17,21$ \\
\hline Miscellaneous chorate forms (excluding Spiniferites spp.) --------- & 7 & 14 \\
\hline 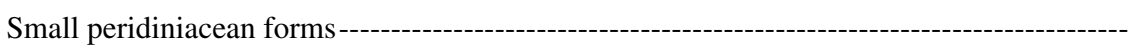 & 7 & $10-13,20$ \\
\hline
\end{tabular}




\section{MILLHAVEN TEST HOLE}

The Millhaven test hole (33X048) was drilled by the U.S. Geological Survey at lat 32 ${ }^{\circ} 53^{\prime} 25^{\prime \prime}$ N., long 81 ${ }^{\circ} 35^{\prime} 43^{\prime \prime}$ W., near Sylvania, Burtons Ferry Landing 7.5-min quadrangle, Screven County, Ga. (fig. 1). The surface elevation is $110 \mathrm{ft}$ above sea level. Sixteen Upper Cretaceous samples were examined for pollen and dinoflagellates from the depth interval of 1,212.0 to $680.8 \mathrm{ft}$ (table 1). Stratigraphic occurrences of angiosperm pollen taxa in the productive samples are shown in figure 3; many of these samples also contained the Cretaceous gymnosperm pollen genus Rugubivesiculites Pierce. Taxon occurrences of dinoflagellates in 10 samples are shown in figure 4.

\section{CAPE FEAR FORMATION}

No palynological samples were studied from the Cape Fear Formation in the Millhaven core.

\section{MIDDENDORF FORMATION}

\section{SUBUNIT 2}

Sample R4664 BA, from a 1,212.0-ft depth, is from subunit 2 of the Middendorf Formation. It contains only two useful angiosperm pollen taxa (fig. 3). Both of these range throughout Zone V (fig. 2), which is equivalent to the combined Complexiopollis exigua-Santalacites minor, Pseudoplicapollis longiannulata-Plicapollis incisa, and ?Pseudoplicapollis cuneata-Semioculopollis verrucosa Zones (fig. 2) of Coniacian, Santonian, and earliest Campanian age. The same sample contains rare dinoflagellate cysts of Palaeohystrichophora infusorioides Deflandre and other peridiniacean forms, which suggests a marginal marine or very nearshore marine environment.

\section{BLACK CREEK GROUP}

\section{SUBUNIT 1}

Sample R4664 CA, from a depth of $1,124.3$ to $1,124.7$ $\mathrm{ft}$ in the Millhaven test hole, is from subunit 1 of the Black Creek Group. Pollen taxa occurrences in this sample are shown in figure 5. Six species are not known to range higher, or they barely range higher, than the top of the ?Pseudoplicapollis cuneata-Semioculopollis verrucosa
Zone. Because of the presence of these taxa, Clarke and others (1996) interpreted this sample as being Santonian in age and as belonging to Zone V (fig. 2). It should be noted that Praecursipollis plebius Tschudy apparently has not been reported from the Atlantic Coastal Plain and is known only from a single sample of the Eutaw Formation in western Georgia (Tschudy, 1975). Sohl and others (1991) considered the Eutaw Formation to be middle Coniacian to late (but not latest) Santonian in age in western Georgia. This formation age is used for the age range of Praecursipollis plebius Tschudy shown in figure 5 and other range charts of this paper that include this species. A very similar species, Praecursipollis sp. A of Christopher (1979), has a range in New Jersey from the base of the Complexiopollis exigua-Santalacites minor Zone to the lower part of the ?Pseudoplicapollis cuneata-Semioculopollis verrucosa Zone; thus, Praecursipollis sp. A has a range virtually identical to the range shown for Praecursipollis plebius Tschudy in this paper.

CP3B-1 and CP3B-6 of Wolfe (1976) are known from the uppermost part of the ?Pseudoplicapollis cuneata-Semioculopollis verrucosa Zone, but they are not known to coexist with Complexiopollis exigua Christopher, Momipites sp. I of Christopher (1979), and New genus D, sp. L of Christopher (1979). CP3B-1 and CP3B-6 belong to the Holkopollenites complex, which is as yet poorly described and only partly illustrated. This complex is mainly developed in the Campanian and Maastrichtian although it has its range base in the Santonian (Christopher, 1982a).

PR-1 of Wolfe (1976), Proteacidites sp. aff. PR-3 of Wolfe (1976), and CP3D-3 of Wolfe (1976) might be contaminants, presumably from drilling mud, or they might have been misidentified. A more likely explanation for the species range pattern in figure 5 is that sample R4664 CA contains a number of reworked taxa from the Coniacian and Coniacian to Santonian, but the sample is probably assignable to mid-Campanian Zone CA-4.

Sample R4664 CA contains rare dinoflagellates of Palaeohystrichophora infusorioides Deflandre, other peridiniacean forms, and miscellaneous areoligeracean forms (fig. 4), suggesting a marginal marine or very nearshore marine environment. These dinoflagellate specimens might be reworked. However, this possibility is unlikely because (1) the specimens are fragile and would not withstand reworking while remaining in a fair state of preservation, and (2) formations from which they might be reworked (Cape Fear and Middendorf) are entirely or nearly entirely nonmarine. 


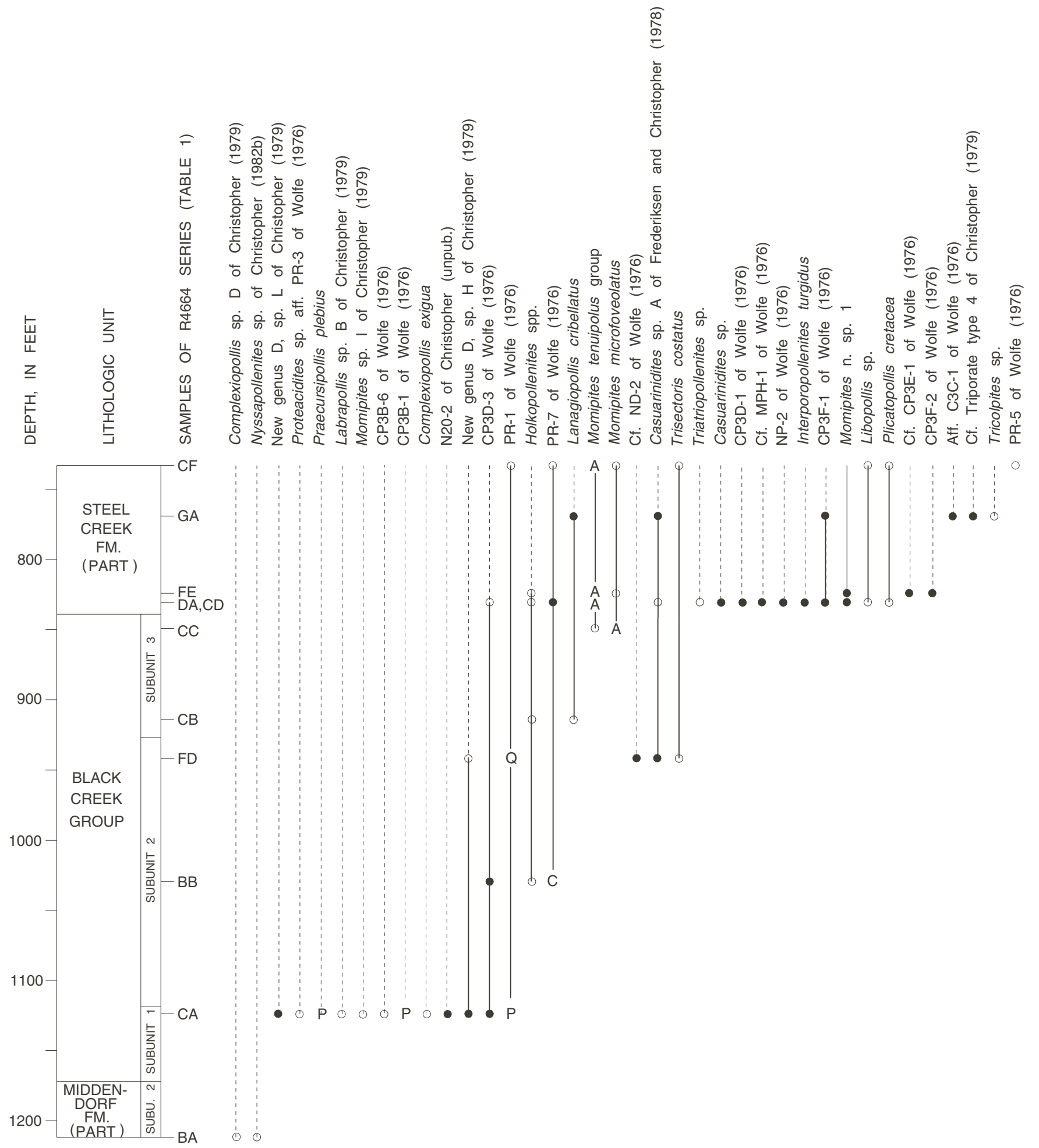

Figure 3. Chart showing pollen taxa occurrences in 11 samples between 1,212.0 and $733.2 \mathrm{ft}$ in the Millhaven core, Screven County, Ga. Solid circles indicate that the identification of the specimens was checked by R.A. Christopher from photomicrographs provided by the senior author; hollow circles indicate that the identification of the specimens was not so checked;
$\mathrm{A}=$ aff., meaning the specimens observed were similar to the taxon listed but probably belong to a different species; $\mathrm{C}=\mathrm{cf}$., meaning that the specimens are similar to and may well belong to the taxon listed; P indicates that the specimens probably belong to the taxon listed; $\mathrm{Q}$ indicates that identification of the taxon was questionable, uncertain. Depths are in feet below land surface. FM., Formation. 


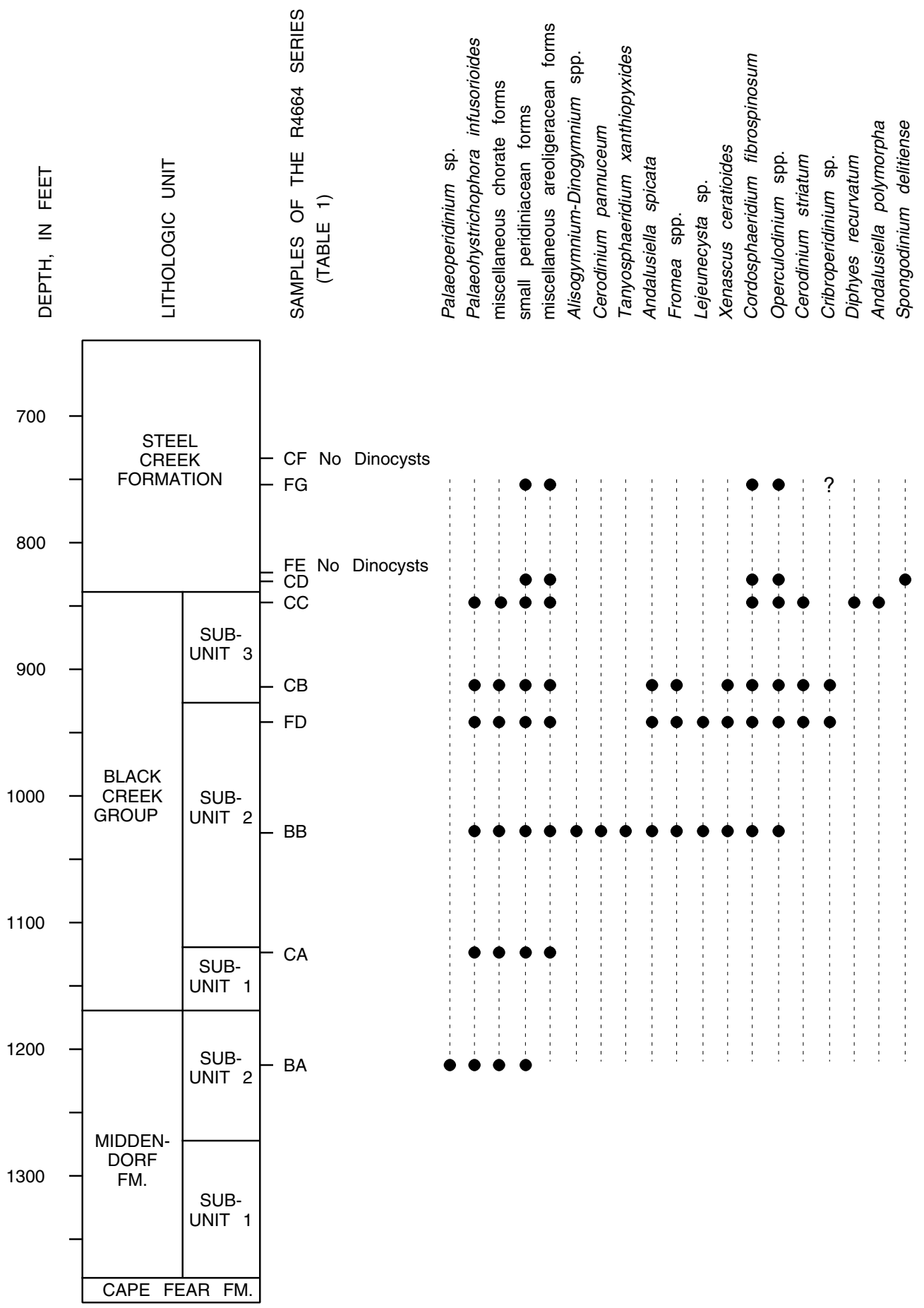

Figure 4. Chart showing dinoflagellate taxa occurrences in 10 samples between 1,212.0 and 680.8 $\mathrm{ft}$ in the Millhaven core, Screven County, Ga. Depths are in feet below land surface. FM., Formation. 


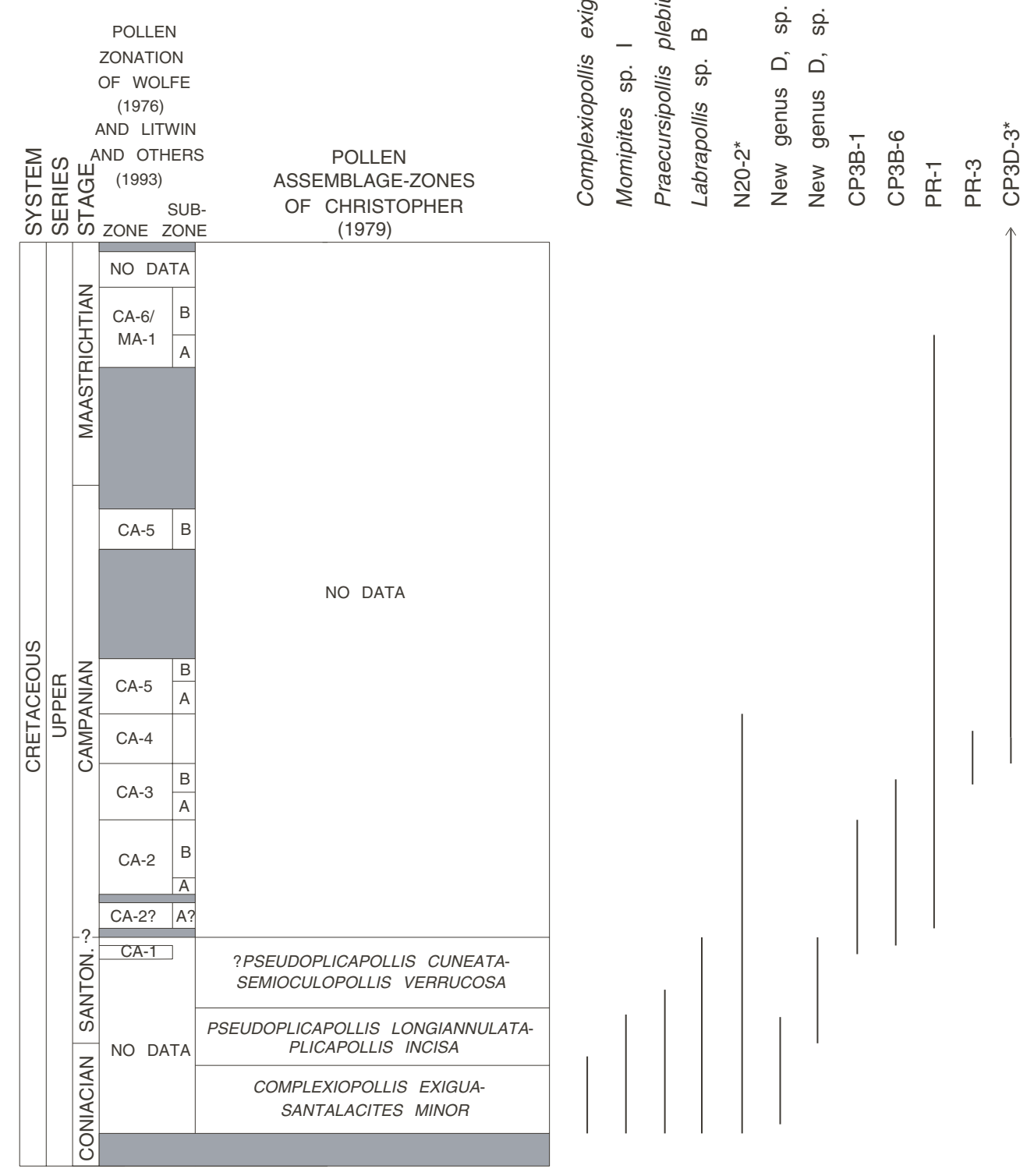

Figure 5. Chart showing known stratigraphic ranges of pollen taxa in sample R4664 CA, subunit 1 of the Black Creek Group, from 1,124.3-1,124.7 ft in the Millhaven core, Screven County, Ga. The known range shown for N20-2 of R.A. Christopher (unpublished) is from Christopher (written commun., 1996). The identification of taxa followed by an asterisk was checked by R.A. Christopher from photomicrographs provided by the senior author; therefore, these taxa are of greater significance than the others. Full names of taxa are in figure 3 and table 4. 


\section{SUBUNIT 2}

Pollen grains and dinoflagellates were examined from two samples of subunit 2 of the Black Creek Group in the Millhaven core. They are R4664 BB and R4664 FD (figs. 3, 4).

Pollen taxa occurrences in sample R4664 BB, from a 1,029.5-ft depth, are shown in figure 6. The stratigraphic ranges are not very informative except to indicate that the age of the sample is probably late Campanian or Maastrichtian. However, Bukry (this volume, chap. D) reports that on the basis of calcareous nannofossils the interval between 1,077.0 and $968.0 \mathrm{ft}$ is late Campanian (Zone CC 22) in age.

Sample R4664 FD, from a depth of 941.7 to $941.9 \mathrm{ft}$, contains mainly long-ranging pollen taxa (fig. 7). Interpretation of the stratigraphic ranges is complicated by the fact that the specimen identified as cf. ND-2 only probably belongs to species ND-2 of Wolfe (1976), and the identification of species PR-1 of Wolfe (1976) was even more tenuous. However, like the underlying sample R4664 BB, this sample cannot be older than late Campanian; therefore, the specimen of New genus D, sp. H of Christopher (1979) is reworked or was misidentified, or its range should be extended upward.

Dinoflagellates are moderately abundant and diverse in samples R4664 BB and FD (1,029.5 and 941.7-941.9 ft, respectively; fig. 4). Important species include Andalusiella spicata (May) Lentin \& Williams, Cerodinium striatum (Drugg) Lentin \& Williams, Cerodinium pannuceum (Stanley) Lentin \& Williams, Palaeohystrichophora infusorioides Deflandre, and Xenascus ceratioides (Deflandre) Lentin \& Williams. The assemblage indicates correlation with the Mount Laurel Formation in New Jersey. This is because the first two species have their lowest occurrences in the Mount Laurel Formation and the last three species have their highest occurrences near the top of the Mount Laurel Formation (May, 1980). As previously stated, we consider the Mount Laurel Formation to be upper Campanian. However, late Campanian calcareous nannofossils were only found as high as $968.0 \mathrm{ft}$ (Bukry, this volume, chap. D). Therefore, the possibility cannot be excluded that some of the stratigraphically highest occurrences of diverse dinoflagellate assemblages in the Millhaven core (as well as in the Girard and Thompson Oak cores) might be correlative with the uppermost Campanian part of the Mount Laurel-Navesink unconformity (fig. 2), that is, slightly younger than the preserved Mount Laurel Formation itself.

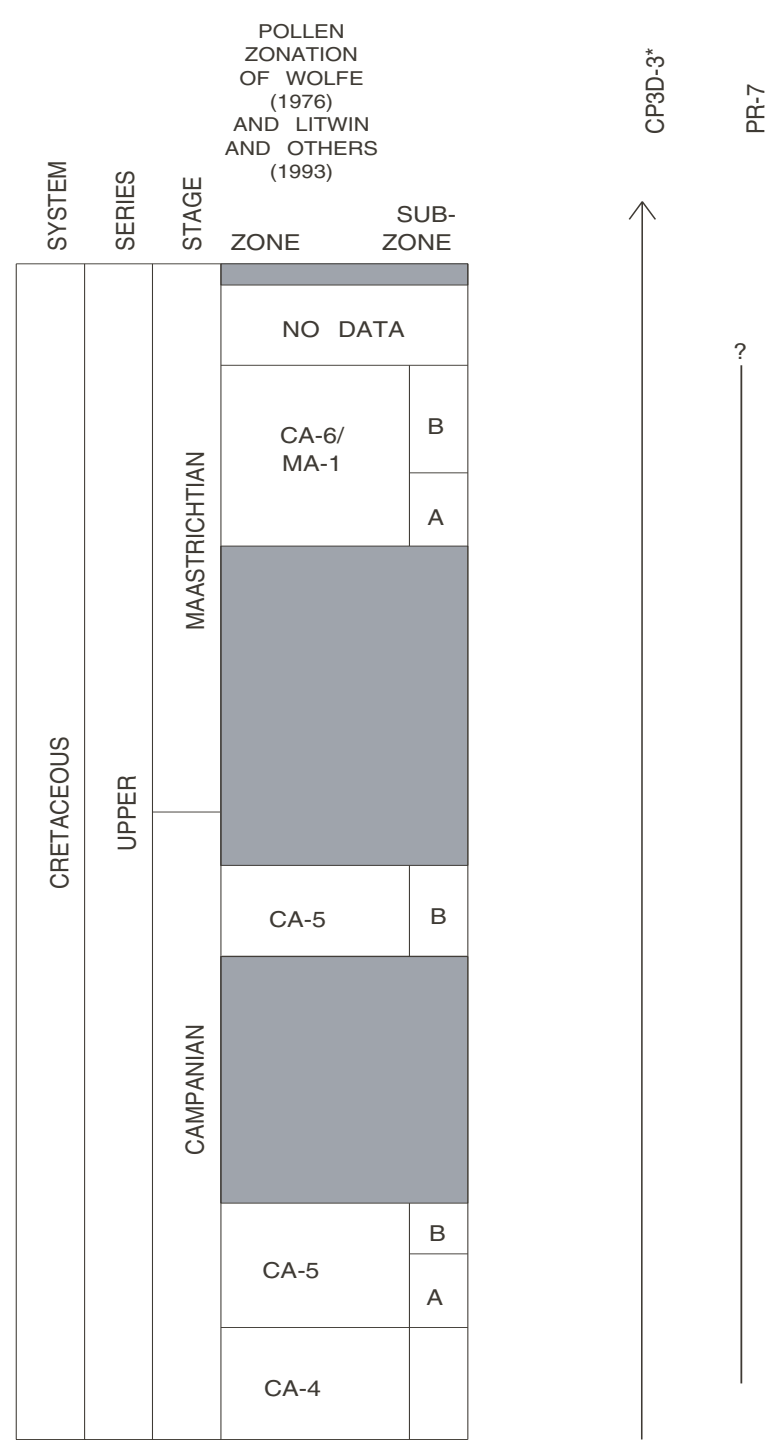

Figure 6. Chart showing known stratigraphic ranges of pollen taxa in sample R4664 BB, subunit 2 of the Black Creek Group, from 1,029.5 ft in the Millhaven core, Screven County, Ga. The identification of the taxon followed by an asterisk was checked by R.A. Christopher from photomicrographs provided by the senior author; therefore, this taxon is of greater significance than the other. Full names of taxa are in figure 3 and table 4 . The question mark indicates that the youngest age of the taxon is uncertain. 


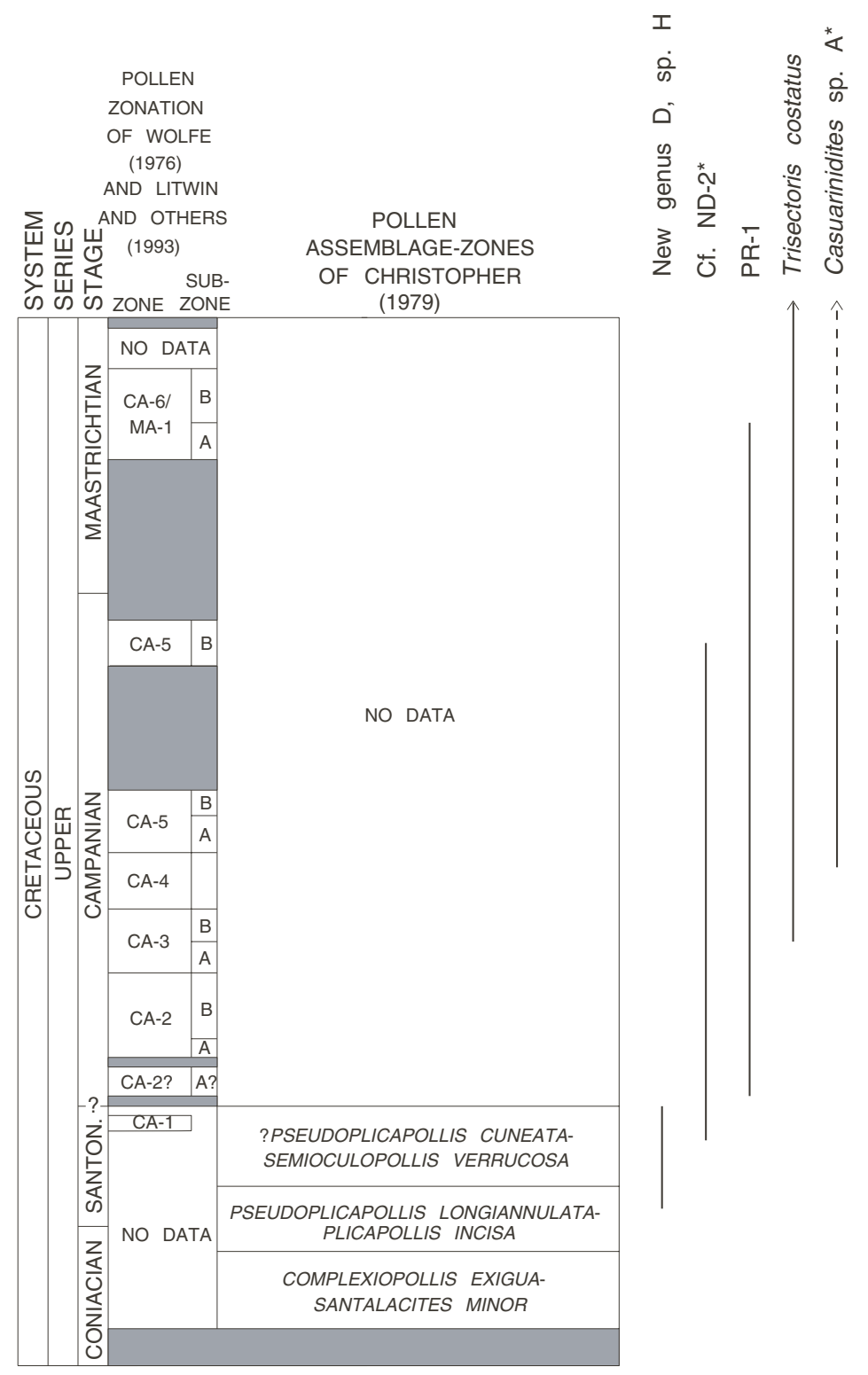

Figure 7. Chart showing known stratigraphic ranges of pollen taxa in sample R4664 FD, subunit 2 of the Black Creek Group, from 941.7-941.9 ft in the Millhaven core, Screven County, Ga. The identification of taxa followed by an asterisk was checked by R.A. Christopher from photomicrographs provided by the senior author; therefore, these taxa are of greater significance than the others. The stratigraphic range shown for species cf. ND-2 is the known range of ND-2 of Wolfe (1976). The identification of species PR-1 of Wolfe (1976) was uncertain. Full names of taxa are in figure 3 and table 4. 


\section{SUBUNIT 3}

Pollen grains and dinoflagellates were examined from two samples of subunit 3 of the Black Creek Group in the Millhaven core. They are R4664 CB and R4664 CC (figs. 3, 4).

Sample R4664 CB from a depth of 913.8-914.2 ft has only sparse pollen grains that include only a few taxa (fig. 3). The only useful species, Lanagiopollis cribellatus (Srivastava) Frederiksen, ranges from mid-Campanian Zone CA-4 into the Paleocene.

Sample R4664 CC, from 849.3-849.6 ft, contains so few (fig. 3) and such long-ranging pollen taxa that little can be said about its age.

The dinoflagellate assemblage in sample R4664 CB of subunit 3 (913.8-914.2 ft; fig. 4) is virtually identical to the assemblage in the sample below (R4664 FD at 941.7-941.9 $\mathrm{ft}$ ) in subunit 2. Important species include Andalusiella spicata (May) Lentin \& Williams, Cerodinium striatum (Drugg) Lentin \& Williams, Palaeohystrichophora infusorioides Deflandre, and Xenascus ceratioides (Deflandre) Lentin \& Williams. Here again, the assemblage is late Campanian, correlative with the Mount Laurel Formation in New Jersey.

Sample R4664 CC (849.3-849.6 ft) has a less diverse assemblage but contains the highest occurrence of Palaeohystrichophora infusorioides Deflandre. The highest occurrence of $P$. infusorioides Deflandre marks the top of Koch and Olsson's (1977) P. infusorioides Zone, which we now consider to correlate approximately with the Campanian-Maastrichtian boundary.

\section{STEEL CREEK FORMATION}

Ten samples of the Steel Creek Formation from the Millhaven test hole were examined for pollen and dinoflagellates. Three samples were barren of both pollen and dinoflagellates (table 1): R4664 FF, CE, and CG. A fourth sample-R4664 GB-contains practically no pollen and only late Paleocene dinoflagellates, which are clearly contaminants from uphole. The six samples providing biostratigraphic information are discussed below.

Figure 8 displays stratigraphic ranges of pollen taxa in three Steel Creek samples from between depths of 830.5 and $824.1 \mathrm{ft}$ in the Millhaven test hole:
Sample
Depth below land
surface, in feet
R4664 FE 824.1-824.4
R4664 DA $\quad 829.5-829.8$
R4664 CD 830.3-830.5

These three samples contain many taxa that were not found to range lower in the Millhaven core section. These pollen taxa include several reworked forms from the Santonian and lower Campanian, but the bulk of the evidence points to a Campanian or Maastrichtian age. The apparent presence of CP3E-1 of Wolfe (1976) and cf. MPH-1 of Wolfe (1976) suggests an assignment to Zone CA-5, of middle to late Campanian age. However, the specimen of cf. MPH-1 may have been misidentified or may be reworked, and CP3E-1 might be observed to range up into the early Maastrichtian if strata of that age are found preserved in certain parts of the coastal plain. The critical taxon in these samples is a new species, Momipites n. sp. 1 (pl. 1, figs. 6, 7, 10-12), known only from the Maastrichtian (R.A. Christopher, written commun., 1996). However, the species might possibly be determined to range down into the uppermost Campanian if strata of that age are locally found to be preserved. Furthermore, the pollen assemblage in sample R4664 DA includes a specimen of Interporopollenites turgidus Tschudy (pl. 2, fig. 2), which apparently has previously been known only from the lower Paleocene (Tschudy, 1975). This specimen may represent contamination from drilling mud, but it appears more likely that this occurrence demonstrates that the species actually ranges, in the form of rare specimens, down into the Upper Cretaceous. If this is so, then the presence of Interporopollenites turgidus Tschudy would also suggest that the samples are Maastrichtian. In summary, because reworking and misidentification are more likely than contamination from uphole, samples R4664 CD, DA, and FE are most likely Maastrichtian in age.

Sample R4664 CD, from a depth of 830.3-830.5 ft in the Steel Creek Formation, contains a rather sparse dinoflagellate assemblage. The presence of Spongodinium delitiense (Ehrenberg) Deflandre, which has its lowest occurrence in the upper part of the Mount Laurel Formation in New Jersey (May, 1980), indicates that the sample is late Campanian or Maastrichtian.

Sample R4664 FE, from 824.1-824.4 ft, does not contain dinoflagellates; sample R4664 DA, from 829.5-829.8 $\mathrm{ft}$, was not examined for these fossils.

In summary, the Campanian-Maastrichtian boundary in the Millhaven core appears to be between 849.3-849.6 and 830.3-830.5 ft, apparently coinciding with the boundary between the Black Creek Group and the Steel Creek Formation at $839.0 \mathrm{ft}$. This is because the last occurrence of Palaeohystrichophora infusorioides Deflandre is at 849.3$849.6 \mathrm{ft}$ and the species is not known to range higher than the Campanian (as the Campanian-Maastrichtian boundary is defined in Burnett, 1996), and the first appearance of 


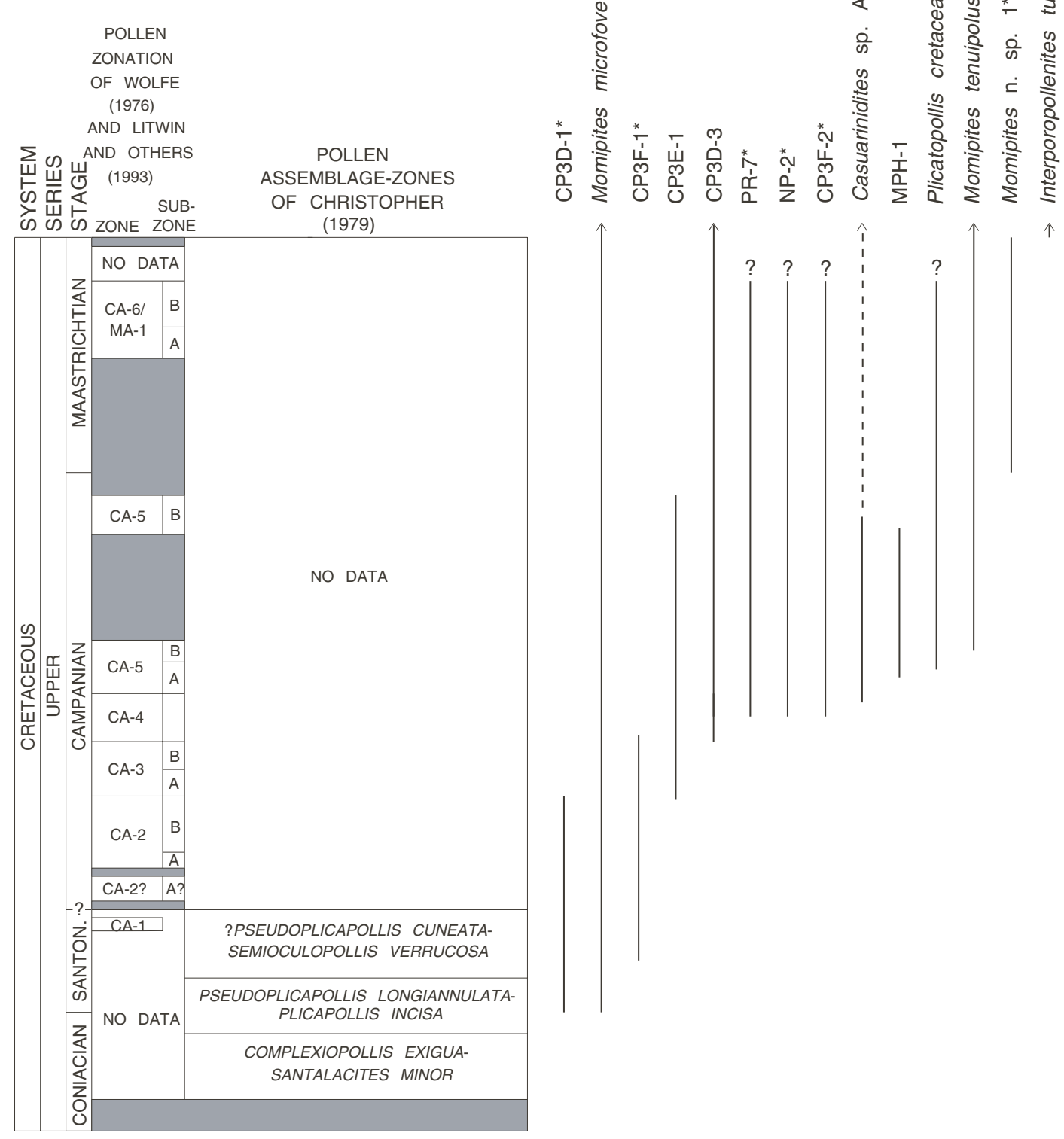

Figure 8. Chart showing known stratigraphic ranges of pollen taxa in three samples (R4664 CD, DA, and FE) from the Steel Creek Formation between 830.5 and $824.1 \mathrm{ft}$ in the Millhaven core, Screven County, Ga. The identification of taxa followed by an asterisk was checked by R.A. Christopher from photomicrographs provided by the senior author; therefore, these taxa are of greater significance than the others. The identification of CP3E-1 of Wolfe (1976) and MPH-1 of Wolfe (1976) was only probable; the range lines show the known stratigraphic ranges of the species themselves. Full names of taxa are in figure 3 and table 4 . 
Maastrichtian pollen species Momipites n. sp. 1 is at $830.3-$ $830.5 \mathrm{ft}$.

Sample R4664 GA, from a depth of 769.0 to $769.3 \mathrm{ft}$, contains pollen species CP3F-1 of Wolfe (1976), not thought to range higher than the mid-Campanian, as well as Casuarinidites sp. A of Frederiksen and Christopher (1978) and Lanagiopollis cribellatus (Srivastava) Frederiksen, which probably range from about the mid-Campanian to near the top or above the top of the Cretaceous (fig. 9). Underlying samples from the Steel Creek Formation are very probably Maastrichtian; therefore, the specimen of CP3F-1 of Wolfe (1976) is presumably reworked. One specimen was found in sample R4664 GA that resembles Triporate type 4 of Christopher (1979), which is known only from one sample from the middle of the Magothy Formation near the Coniacian-Santonian boundary of New Jersey. Either the specimen in the Millhaven core represents a different species, or the species (species group?) actually ranges from the Santonian up to the Maastrichtian, or else the specimen is reworked from older strata. Sample R4664 GA lacks dinoflagellates.

Sample R4664 FG, from a depth of 755.0 to $755.3 \mathrm{ft}$, does not contain any known Cretaceous pollen grains. Instead, it has the lower Tertiary taxa Sparganiaceaepollenites sp., Plicatopollis triradiatus (Nichols) Frederiksen \& Christopher, and Momipites-Plicatopollis-Platycaryapollenites complex of Frederiksen (1979). These specimens no doubt represent contamination of the sample by drilling mud. This sample also contains sparse dinoflagellates (fig. 4) that may be either indigenous (Late Cretaceous), indicating at least a marginally marine environment of deposition, or may be Tertiary specimens representing contamination from uphole.

Sample R4664 CF, from a depth of 733.2 to $733.3 \mathrm{ft}$, apparently is late Campanian or early Maastrichtian in age according to the ranges of its pollen taxa (fig. 10). Because of the apparent Maastrichtian age of samples lower in the section (fig. 8), this is also probably Maastrichtian. This sample lacked dinoflagellates.

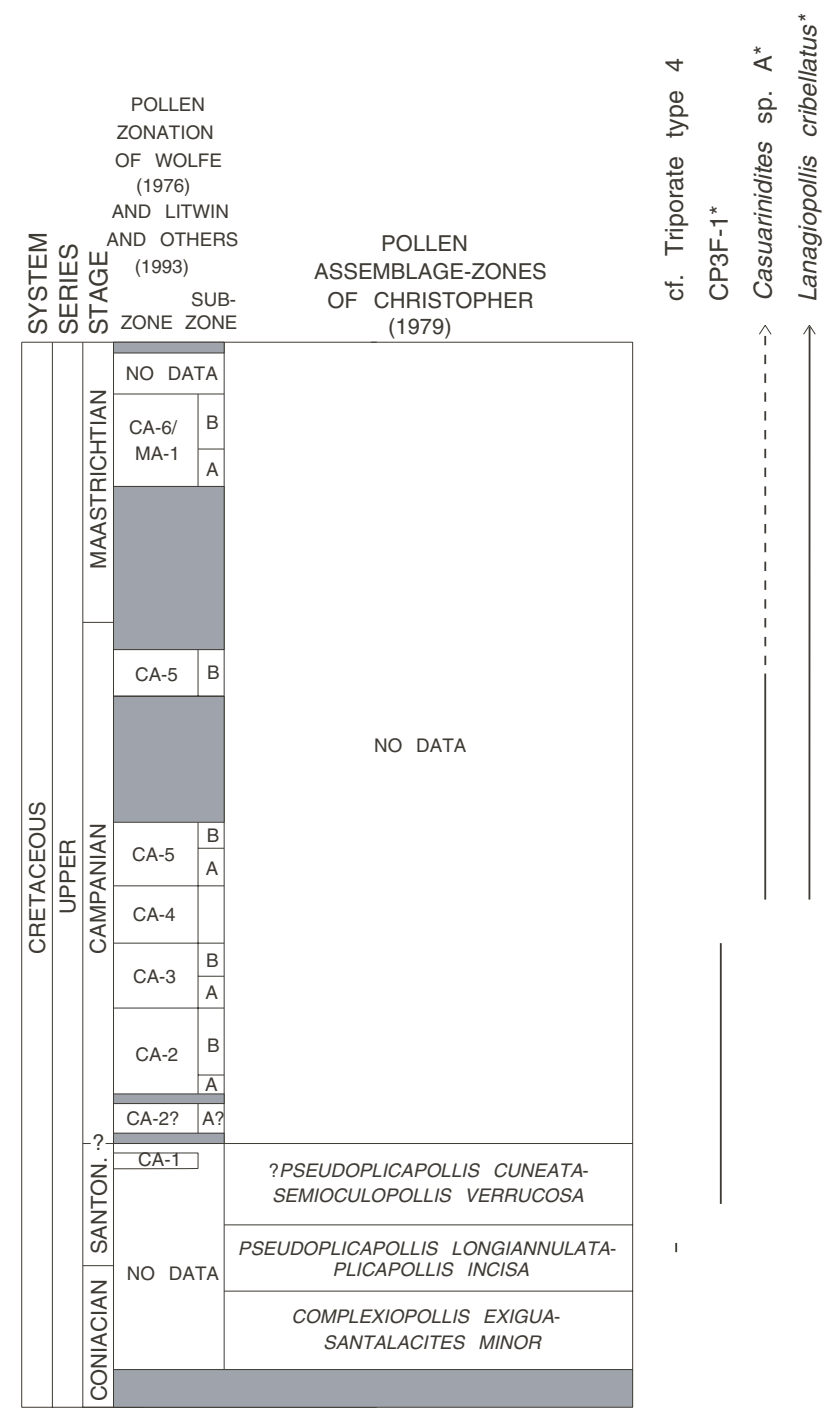

Figure 9. Chart showing known stratigraphic ranges of pollen taxa in sample R4664 GA, Steel Creek Formation, from 769.0$769.3 \mathrm{ft}$ in the Millhaven core, Screven County, Ga. The identification of taxa followed by an asterisk was checked by R.A. Christopher from photomicrographs provided by the senior author; therefore, these taxa are of greater significance than the others. Full names of taxa are in figure 3 and table 4 . A range line for C3C-1 of Wolfe (1976) is not shown because the specimen found is only similar to but probably not the same species as C3C-1. 


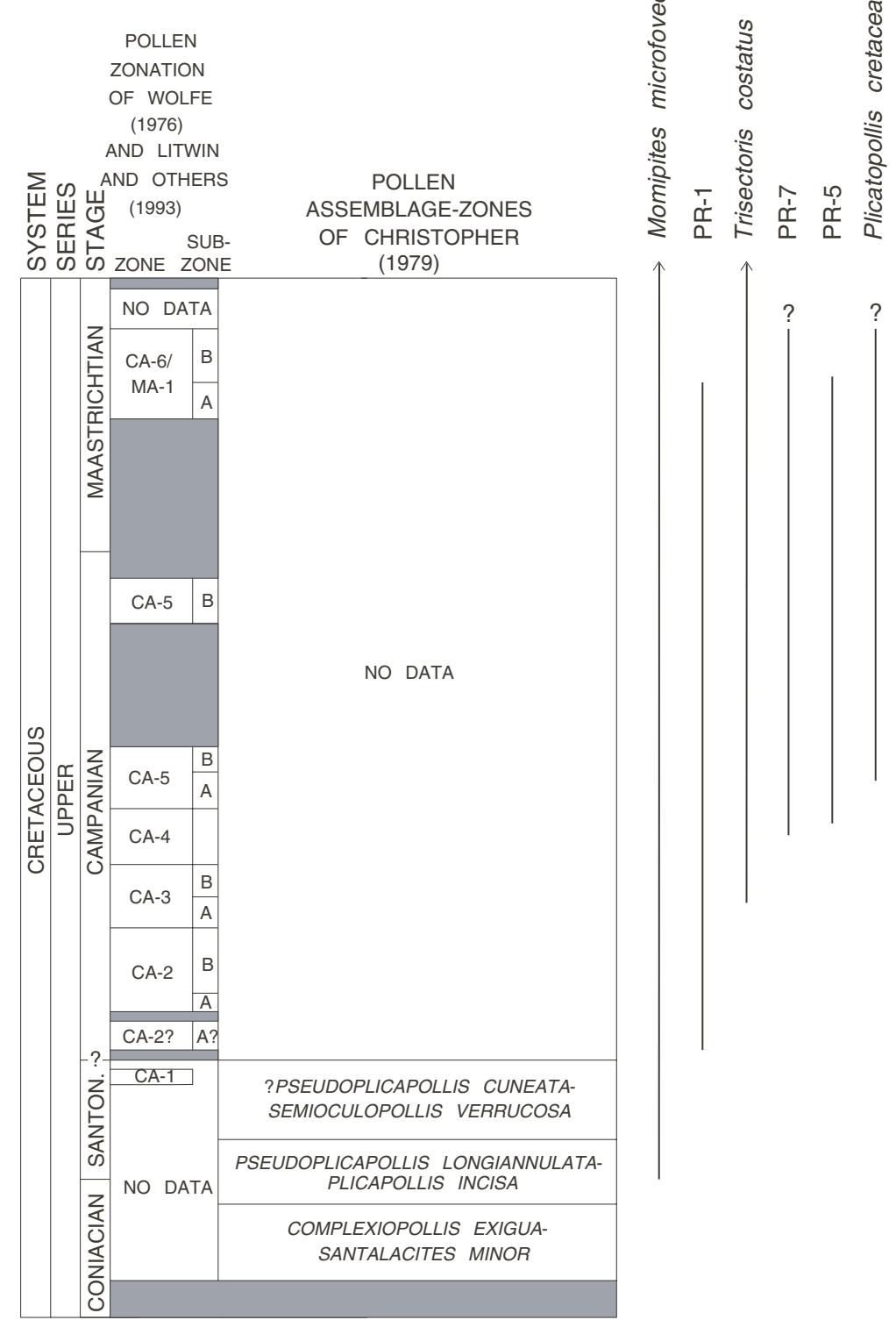

Figure 10. Chart showing known stratigraphic ranges of pollen taxa in sample R4664 CF, Steel Creek Formation, from 733.2-733.3 ft in the Millhaven core, Screven County, Ga. Full names of taxa are in figure 3 and table 4. 


\section{GIRARD TEST HOLE}

The U.S. Geological Survey drilled the Girard test hole (32Y020) in southern Burke County at the lookout tower on Griffins Landing Road, 2 miles north of the town of Girard, at lat $33^{\circ} 03^{\prime} 54^{\prime \prime}$ N., long $81^{\circ} 43^{\prime} 13^{\prime \prime}$ W., Girard 7.5-min quadrangle (fig. 1). The surface elevation is $250 \mathrm{ft}$ above sea level. Nineteen Upper Cretaceous samples from this core were examined for palynomorphs (table 1). Three of these were scanned in detail for pollen (fig. 11), and four samples were scanned in detail for dinoflagellates (fig. 12).

\section{CAPE FEAR FORMATION}

No palynological samples were studied from the Cape Fear Formation in the Girard core.

\section{MIDDENDORF FORMATION}

\section{SUBUNIT 1}

Sample R4705 AA, from a depth of $1,138.0$ to $1,139.0$ $\mathrm{ft}$ in the Girard core, is from subunit 1 of the Middendorf Formation. The sample had only four angiosperm pollen taxa of known stratigraphic range, and the ranges of these are spread throughout the Upper Cretaceous (fig. 13). Therefore, the data are ambiguous. This sample did not contain dinoflagellates, and neither did another sample from subunit 1; the second sample was barren of all palynomorphs.

\section{SUBUNIT 2}

Sample R4705 BA, from a depth of $1,012.0$ to $1,012.3$ $\mathrm{ft}$ in the Girard core, is from subunit 2 of the Middendorf Formation. The sample is similar to sample R4705 AA in containing pollen taxa apparently having disparate stratigraphic ranges (fig. 14). According to R.A. Christopher (written commun., 1996), the pollen flora of the sample from 1,012.0-1,012.3 ft suggests a latest Santonian(?) or earliest Campanian age on the basis of a pollen correlation with the upper part of the Shepherd Grove Formation of the USGS Clubhouse Crossroads core in Dorchester County, S.C. The sample does not appear to correlate with the middle Santonian Middendorf Formation of the Clubhouse Crossroads core (see Gohn, 1992).

Six samples from the Middendorf Formation (subunit 2) were examined for dinoflagellates (fig. 12), but none contained these fossils; therefore, these samples are assumed to be nonmarine.

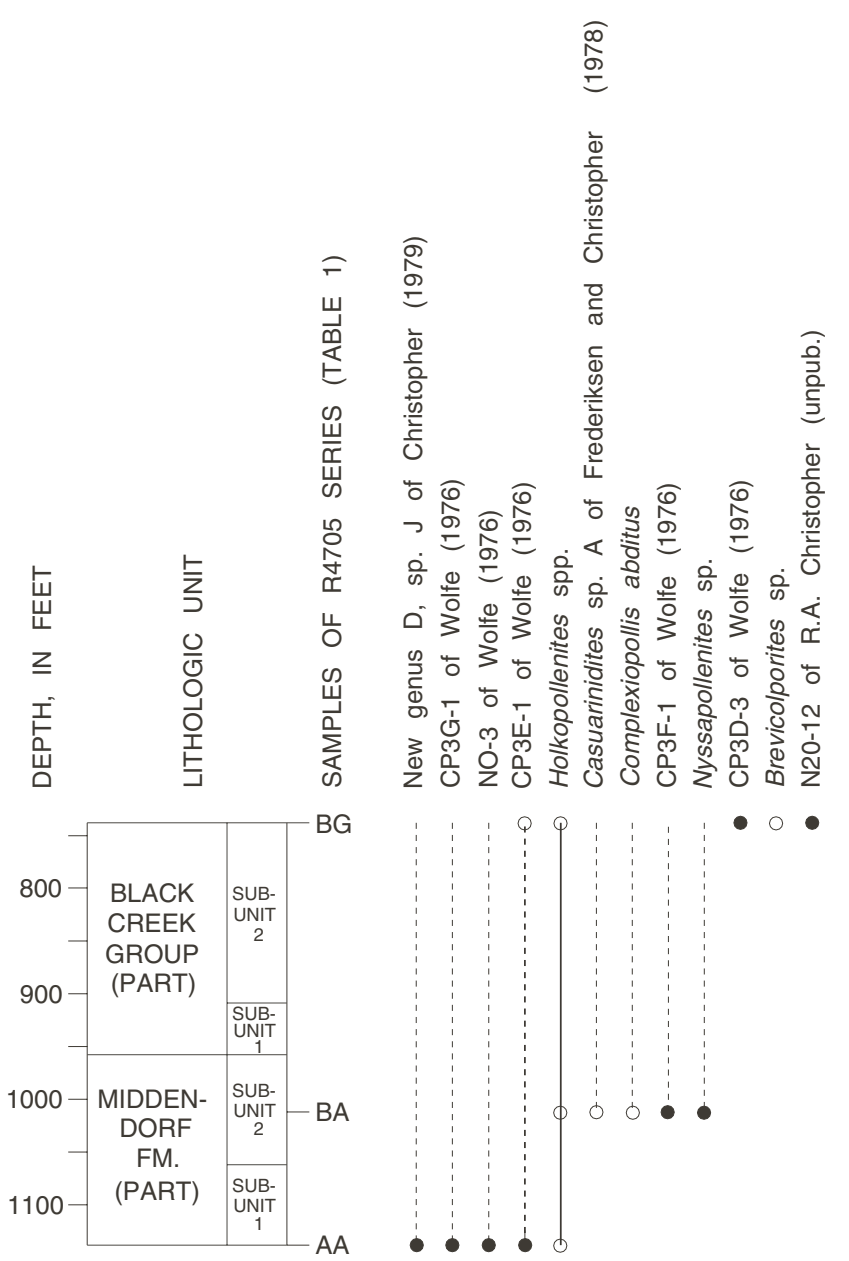

Figure 11. Chart showing pollen taxa occurrences in three samples between 1,139.0 and $738.3 \mathrm{ft}$ in the Girard core, Burke County, Ga. Solid circles indicate that the identification of the specimens was checked by R.A. Christopher from photomicrographs provided by the senior author; hollow circles indicate that the identification of the specimens was not so checked. Depths are in feet below land surface. FM., Formation. 


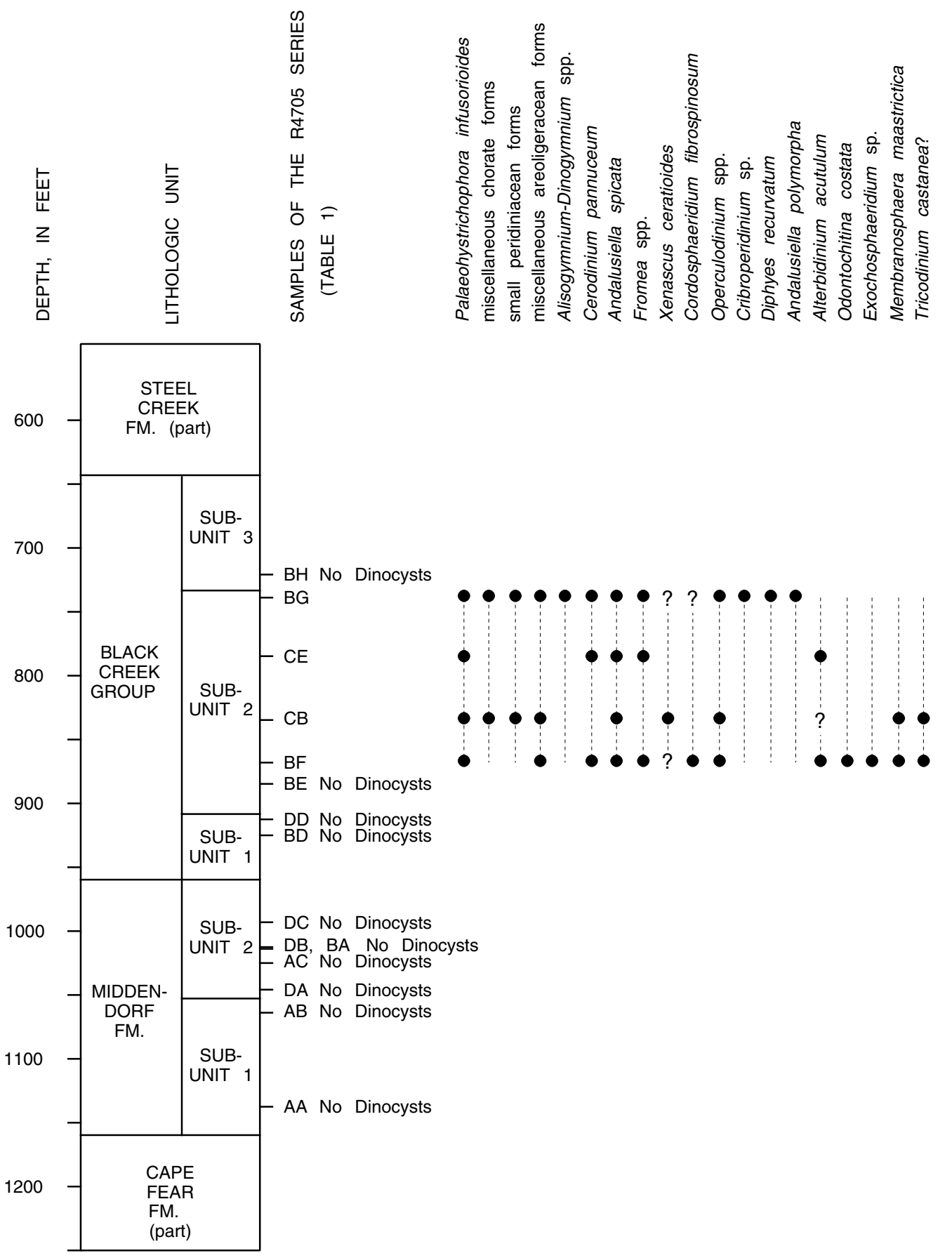

Figure 12. Chart showing dinoflagellate taxa occurrences in 15 samples between $1,139.0$ and $720.3 \mathrm{ft}$ in the Girard core, Burke County, Ga. Depths are in feet below land surface. FM., Formation. Four samples were scanned in detail for dinoflagellates. Question marks within range lines indicate uncertainty of identification. 


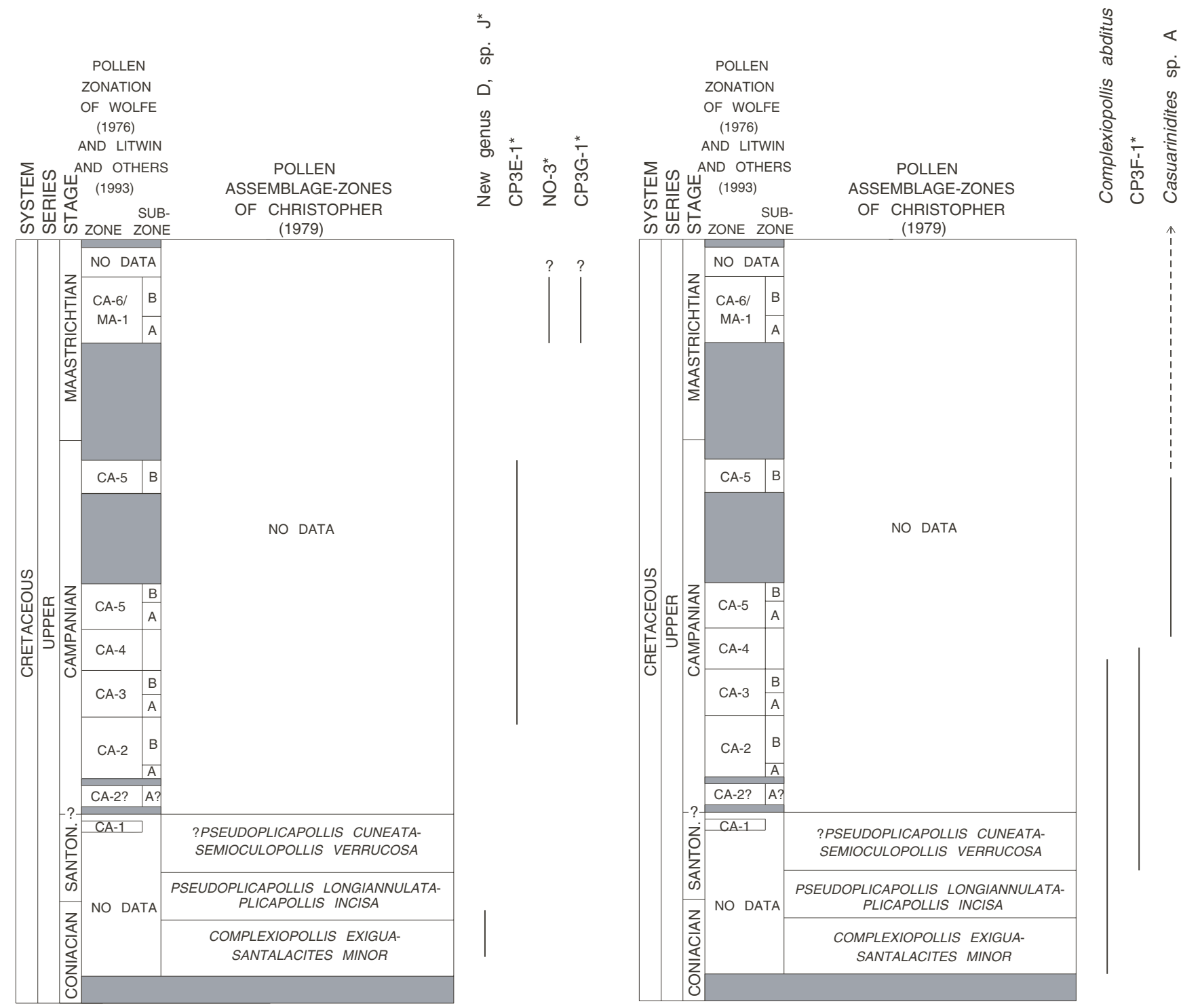

Figure 13. Chart showing known stratigraphic ranges of pollen taxa in sample R4705 AA, subunit 1 of the Middendorf Formation, from 1,138.0-1,139.0 ft in the Girard core, Burke County, Ga. Taxa followed by an asterisk indicate that identification of the specimens was checked by R.A. Christopher from photomicrographs provided by the senior author. Full names of taxa are in figure 11 and table 4. Question marks indicate that the youngest age of the taxon is uncertain.

Figure 14. Chart showing known stratigraphic ranges of pollen taxa in sample R4705 BA, subunit 2 of the Middendorf Formation, from 1,012.0-1,012.3 ft in the Girard core, Burke County, Ga. The identification of the taxon followed by an asterisk was checked by R.A. Christopher from photomicrographs provided by the senior author; therefore, this taxon is of greater significance than the others. Full names of taxa are in figure 11 and table 4. 


\section{BLACK CREEK GROUP}

The lowest marine palynomorphs in the Black Creek Group in the Girard core were found at $868.5-868.7 \mathrm{ft}$, in subunit 2, and the presence and absence pattern of dinoflagellate occurrences (fig. 12) suggests nonmarine conditions in subunit 1 of the Black Creek Group, then marine conditions in subunit 2, then nonmarine deposition in subunit 3 of the Black Creek. The dinoflagellate-bearing assemblages in the Girard core are not as rich but contain many of the same taxa and are the same age as samples from subunit 2 and the lower part of subunit 3 of the Black Creek Group in the Millhaven core. The taxa found in Black Creek samples from both cores are Palaeohystrichophora infusorioides Deflandre, Xenascus ceratioides (Deflandre) Lentin \& Williams, Cordosphaeridium fibrospinosum Davey \& Williams, and Andalusiella spicata (May) Lentin $\&$ Williams. In the Millhaven core, these assemblages came from strata assignable in part to late Campanian calcareous nannofossil Zone CC 22 (Bukry, this volume, chap. D), and the dinoflagellate assemblages were correlated with those from the upper Campanian Mount Laurel Formation of New Jersey.

Most pollen assemblages from the Black Creek of the Girard core are sparse and not age diagnostic. However, sample R4705 BG, from 738.3 to $738.6 \mathrm{ft}$ (subunit 2 of the Black Creek Group), had two useful pollen taxa (fig. 15), and the overlap of the ranges of these taxa suggests a middle to late Campanian age somewhere within Zone CA-4 or Zone CA-5. As noted above, dinoflagellates from this sample suggest a late Campanian age correlative with the upper part of pollen Zone CA-5.

\section{STEEL CREEK FORMATION}

No palynological samples were studied from the Steel Creek Formation in the Girard core.

\section{THOMPSON OAK TEST HOLE}

The Thompson Oak test hole was drilled by the Georgia Geologic Survey at lat $33^{\circ} 10^{\prime} 42^{\prime \prime}$ N., long $81^{\circ} 47^{\prime} 10^{\prime \prime}$ W., Shell Bluff Landing 7.5-min quadrangle, Burke County, Ga. (fig. 1). The surface elevation is $240 \mathrm{ft}$ above sea level. Two samples were examined from this core.

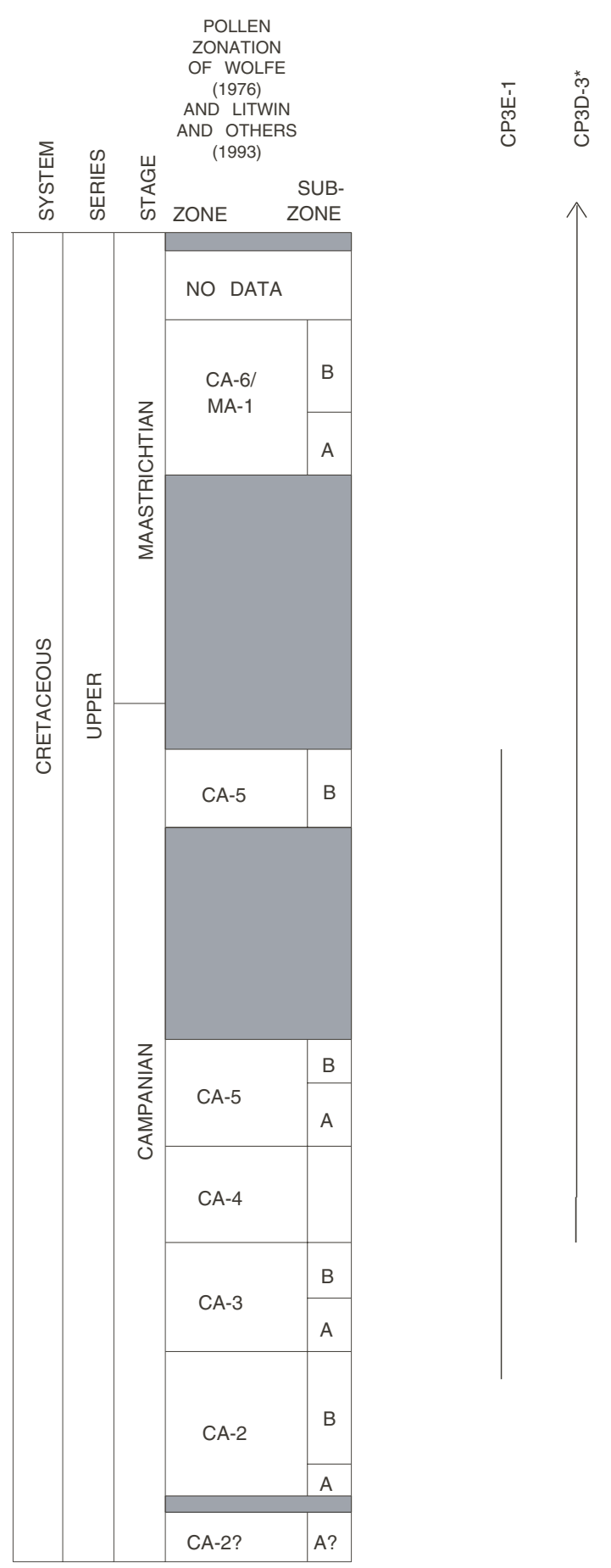

Figure 15. Chart showing known stratigraphic ranges of pollen taxa in sample R4705 BG, subunit 2 of the Black Creek Group, from 738.3-738.6 ft in the Girard core, Burke County, Ga. Not shown is species N20-12 of R.A. Christopher (unpub.), which has a very long stratigraphic range from Zone V (fig. 2) to the Maastrichtian (R.A. Christopher, written commun., 1996). The identification of the taxon followed by an asterisk was checked by R.A. Christopher from photomicrographs provided by the senior author; therefore, this taxon is of greater significance than the other. Full names of taxa are in figure 11 and table 4. 


\section{BLACK CREEK GROUP}

Two samples from the Black Creek Group in the Thompson Oak core were examined for dinoflagellates. The lower sample (R4836 A, $561.0 \mathrm{ft}$ depth) is from a kaolinitic, lignitic, micaceous sand. It contains only three dinoflagellate specimens that do not appear to be marine. The upper sample (R4836 B, $505.0 \mathrm{ft}$ depth) is from a sandy, micaceous, lignitic kaolin and contains a sparse assemblage similar to that of samples R4664 BB to CB (from subunit 2 and the lowermost part of subunit 3 of the Black Creek Group) in the Millhaven core, that is, Palaeohystrichophora infusorioides Deflandre(?), Xenascus ceratioides (Deflandre) Lentin \& Williams, and Andalusiella spicata (May) Lentin \& Williams (fig. 16). These dinoflagellate taxa indicate a nearshore marine to normal marine environment of deposition and a late Campanian age.

\section{MILLERS POND TEST HOLE}

The Millers Pond test hole was drilled by the Georgia Geologic Survey (Burke 2, GGS-3758) near Shell Bluff Landing on the Savannah River, lat $33^{\circ} 13^{\prime} 48^{\prime \prime}$ N., long $81^{\circ} 52^{\prime} 44^{\prime \prime}$ W., McBean 7.5-min quadrangle, Burke County, Ga. (fig. 1). The surface elevation is $245 \mathrm{ft}$ above sea level. Clarke and others (1994) provided a lithologic description of the cored section.

Fifteen samples were collected from Cretaceous strata in this core (table 1) from the depth interval of 852.0 to $282.0 \mathrm{ft}$. Only four contained useful pollen assemblages (fig. 17), and none of the samples contained marine palynomorphs.

\section{CAPE FEAR FORMATION}

Christopher and others (1979) examined samples from the Cape Fear Formation of North Carolina and concluded, on the basis of the pollen flora, that the Cape Fear Formation could be assigned to undifferentiated pollen Zone V, which is approximately equivalent to the combined Complexiopollis exigua-Santalacites minor, Pseudoplicapollis longiannulata-Plicapollis incisa, and ?Pseudoplicapollis cuneata-Semioculopollis verrucosa Zones of Coniacian to earliest Campanian age (fig. 2).
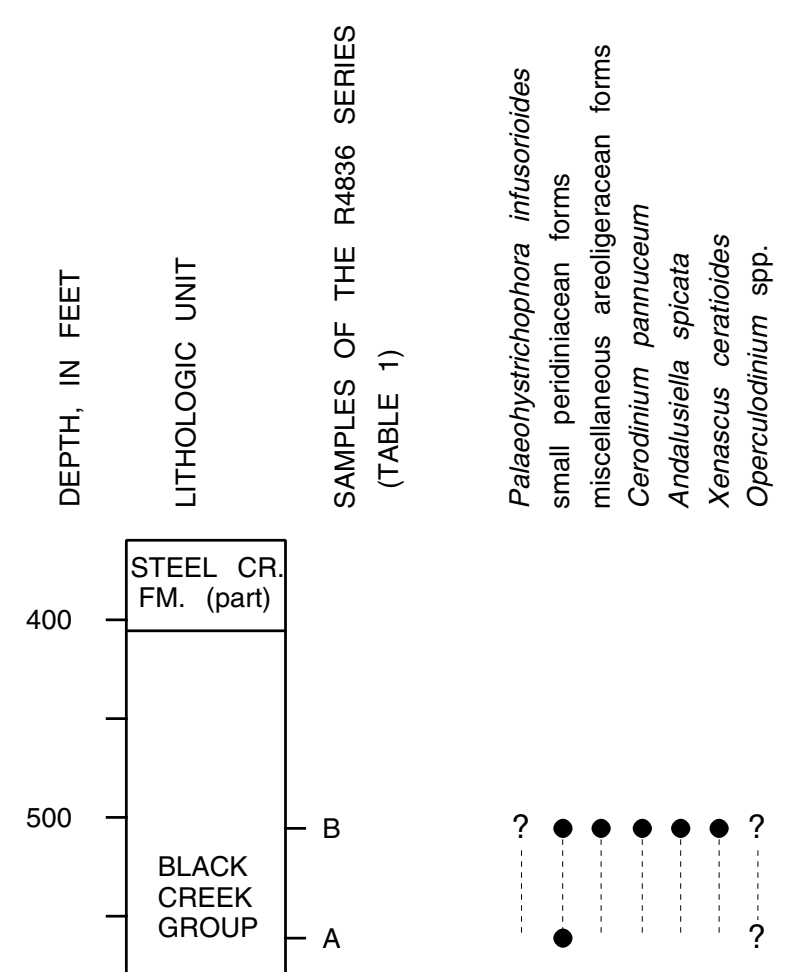

Figure 16. Chart showing dinoflagellate taxa occurrences in two samples from 561.0 and $505.0 \mathrm{ft}$, respectively (Black Creek Group), in the Thompson Oak core, Burke County, Ga. Depths are in feet below land surface. FM., Formation. Full names of taxa are in table 5 . 


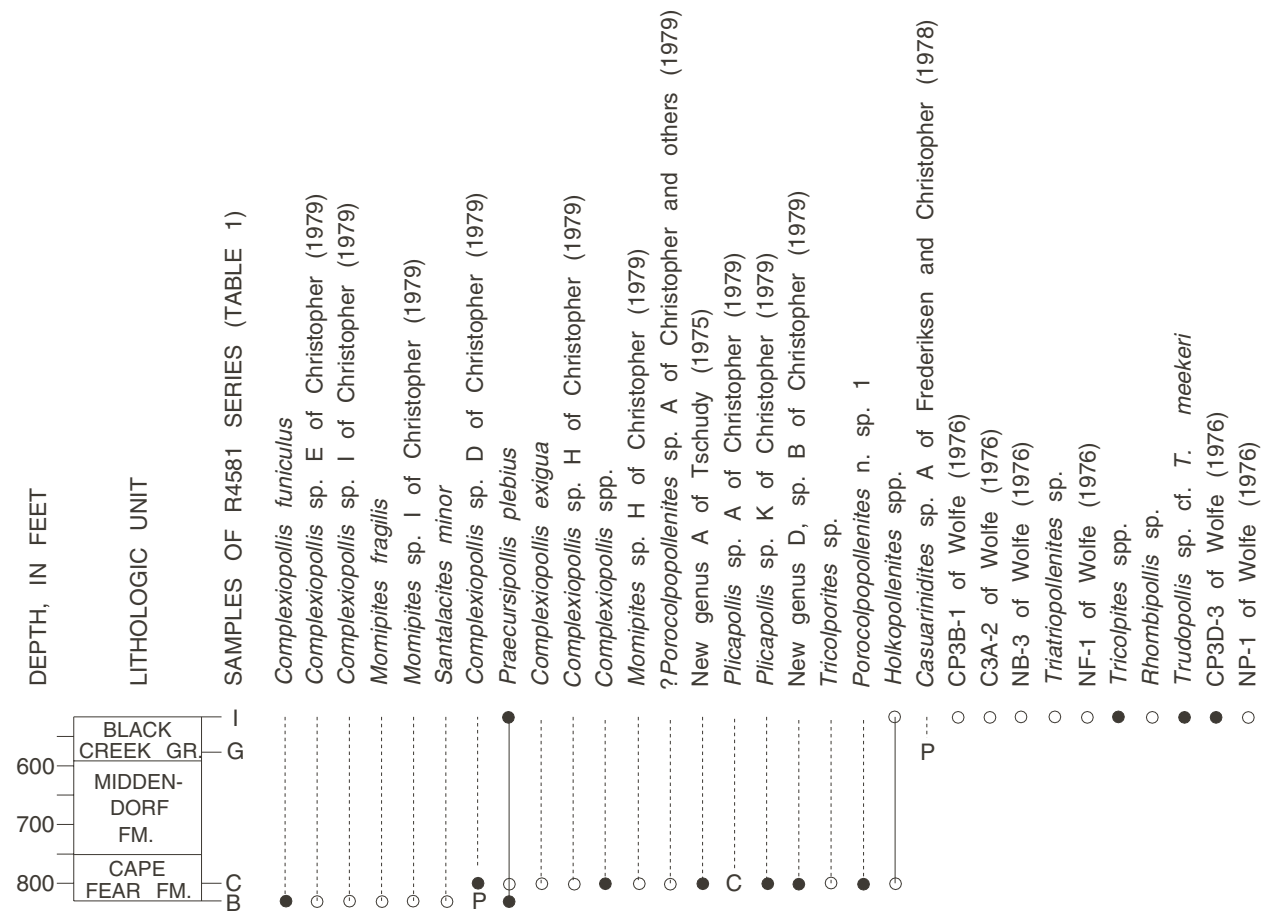

Figure 17. Chart showing pollen taxa occurrences in four samples between 832.0 and $517.0 \mathrm{ft}$ in the Millers Pond core, Burke County, Ga. Solid circles indicate that the identification of the specimens was checked by R.A. Christopher from photomicrographs provided by the senior author; hollow circles indicate that the identification of the specimens was not so checked; $\mathrm{C}=\mathrm{cf}$., meaning that the specimens are similar to and may well belong to the taxon listed; $\mathrm{P}$ indicates that the specimens probably belong to the taxon listed. Depths are in feet below land surface. GR., Group; FM., Formation.

Sample R4581 B, from a depth of 827.0 to $832.0 \mathrm{ft}$ in the Millers Pond core, contains pollen taxa whose ranges suggest assignment to the combined Complexiopollis exigua-Santalacites minor, Pseudoplicapollis longiannulata-Plicapollis incisa, and ?Pseudoplicapollis cuneataSemioculopollis verrucosa Zones (figs. 2, 18; the range of Momipites sp. I of Christopher (1979) is difficult to evaluate because the identification of this species has not been verified). However, sample R4581 C, from a depth of 797.0 to $802.0 \mathrm{ft}$, can be narrowed to the Complexiopollis exigua-Santalacites minor and Pseudoplicapollis longiannulata-Plicapollis incisa Zones (fig. 19) and most likely belongs to the Complexiopollis exigua-Santalacites minor Zone of Coniacian age. Therefore, the underlying sample R4581 B would also belong to this zone. The occurrence of New Genus A of Tschudy (1975) is interesting, as it was previously known only from a single sample of the Eutaw Formation in western Georgia (Tschudy, 1975), which was also the case with Praecursipollis plebius Tschudy (discussed under sample R4664 CA, Black Creek Group of the Millhaven core). Clarke and others $(1994,1996)$ and Leeth and others (1996) considered the Eutaw Formation of the eastern Gulf Coast to be correlative with the Middendorf Formation, not with the Cape Fear Formation, of the Southern Atlantic Coastal Plain. As an alternative interpretation, Prowell, Christopher, and others (1985) correlated the Cape Fear Formation with the lower half of the Eutaw Formation, and the Middendorf Formation with the upper half of the Eutaw Formation.

The lack of both marine palynomorphs (dinoflagellates, acritarchs) and microforaminiferal linings in samples R4581 B and R4581 C suggests a nonmarine environment of deposition for the Cape Fear Formation.

Two additional samples from the Cape Fear Formation, from depths of 847.0-852.0 and $778.0 \mathrm{ft}$, were barren of palynomorphs. 

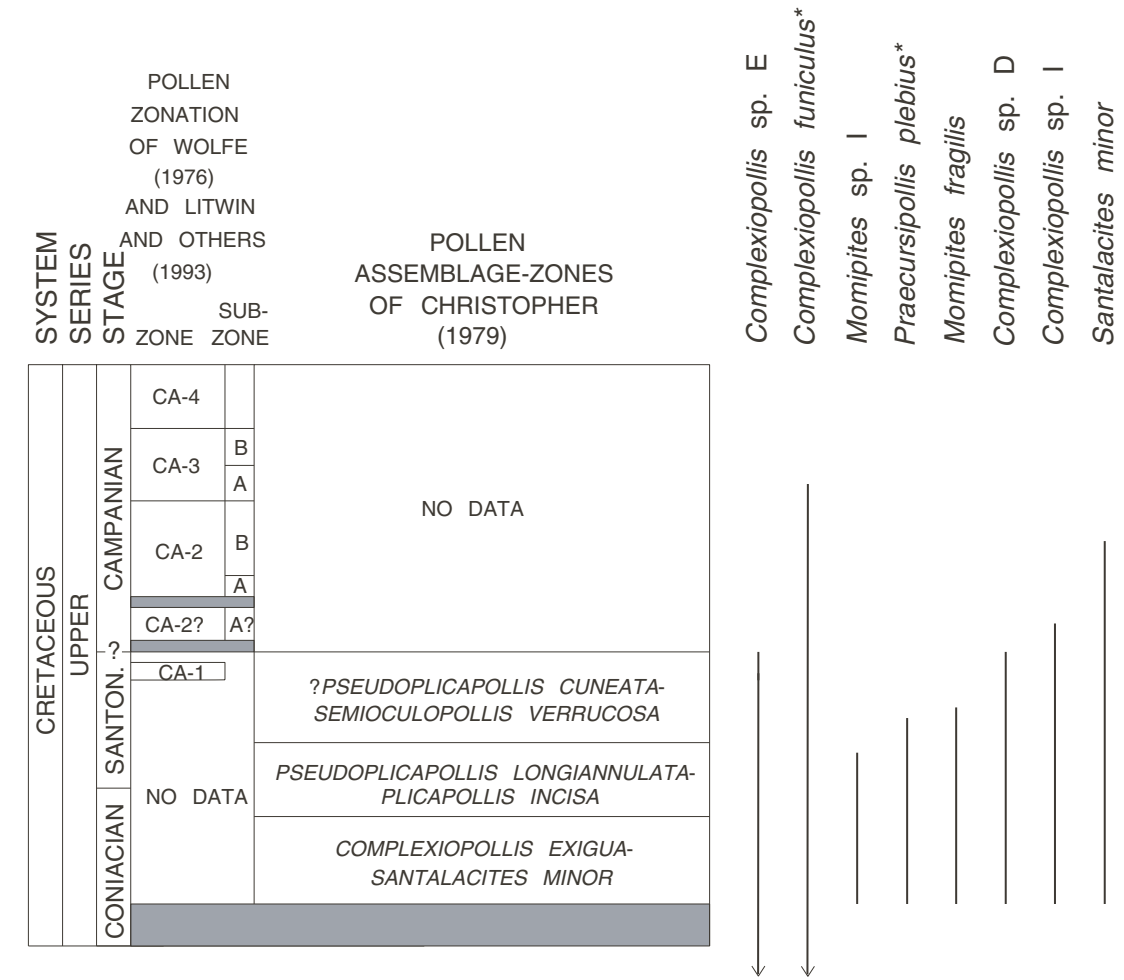

Figure 18. Chart showing known stratigraphic ranges of pollen taxa in sample R4581 B, Cape Fear Formation, from 827.0-832.0 ft in the Millers Pond core, Burke County, $\mathrm{Ga}$. The identification of taxa followed by an asterisk was checked by R.A. Christopher from photomicrographs provided by the senior author; therefore, these taxa are of greater significance than the others. Full names of taxa are in figure 17 and table 4.

\section{MIDDENDORF FORMATION}

No productive palynological samples were studied from the Middendorf Formation in the Millers Pond core.

\section{BLACK CREEK GROUP}

Sample R4581 G, from $578.0 \mathrm{ft}$, contained only rare angiosperm pollen grains; the only useful pollen species (whose identification is probably correct) was Casuarinidites sp. A of Frederiksen and Christopher (1978). In the Middle Atlantic States, this species has a known range base in the mid-Campanian (see fig. 14). However, sample R4705 BA, from the Middendorf Formation of the Girard core, also contains this species (fig. 14). This Girard sample is thought to be uppermost Santonian or lowermost Campanian, suggesting that Casuarinidites sp. A of Frederiksen and Christopher (1978) has its range base near the base of the Campanian. In summary, Millers Pond sample R4581 G may be latest Santonian or earliest Campanian like the Girard sample, or it may be younger.

Sample R4581 I, from $517.0 \mathrm{ft}$, contains taxa having a great variety of known stratigraphic ranges (fig. 20). Praecursipollis plebius Tschudy is probably reworked. If NF-1 and CP3B-1 are reworked or misidentified, the other taxa would suggest a middle to late Campanian age within Zones CA-4 or CA-5. The absence of marine dinoflagellates and microforaminiferal linings in this sample (as in all Cretaceous samples from the Millers Pond core) indicates a nonmarine environment of deposition. 


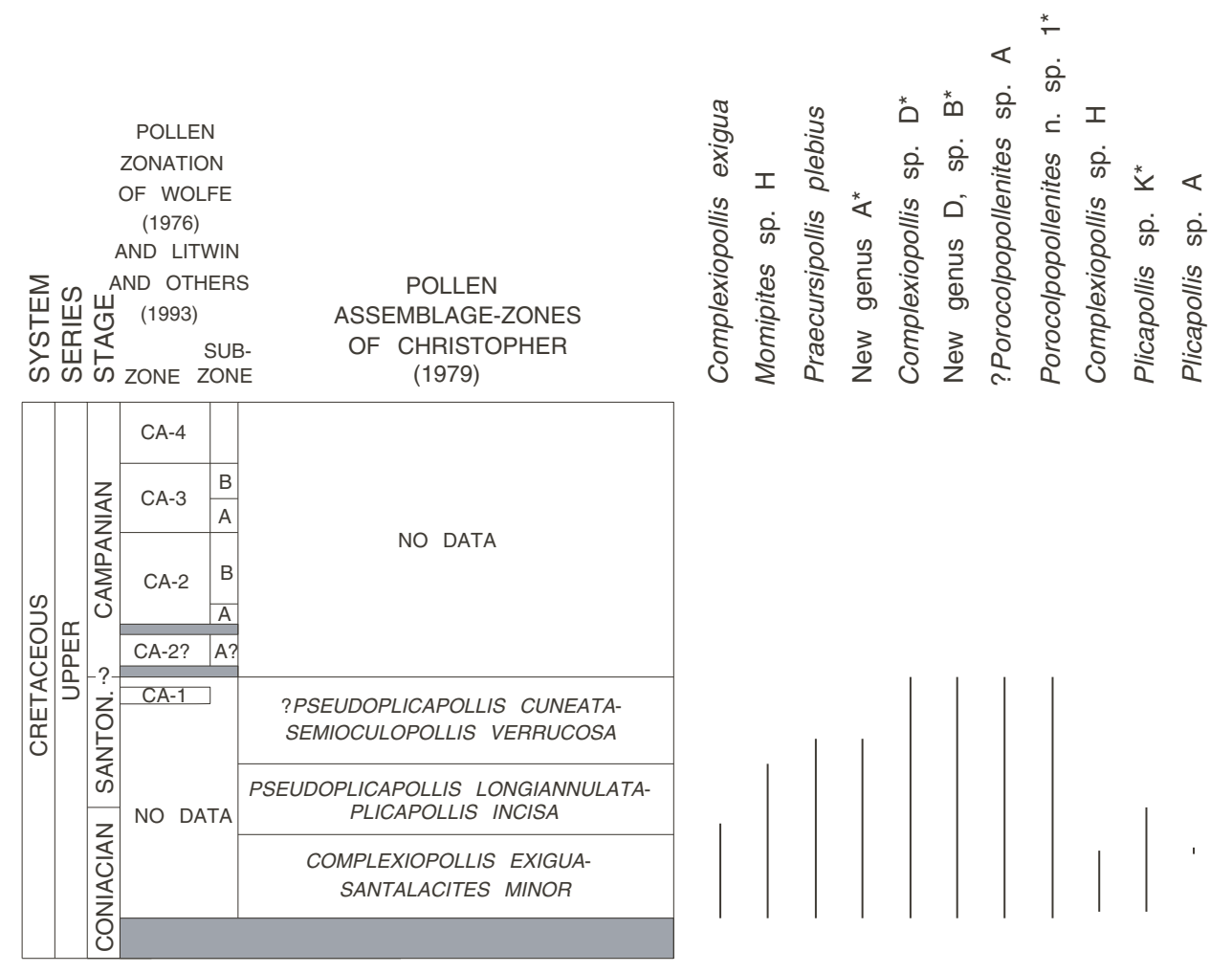

Figure 19. Chart showing known stratigraphic ranges of pollen taxa in sample R4581 C, Cape Fear Formation, from 797.0-802.0 ft in the Millers Pond core, Burke County, Ga. The known range shown for Porocolpopollenites n. sp. 1 is from Christopher (written commun., 1996). The identification of taxa followed by an asterisk was checked by R.A. Christopher from photomicrographs provided by the senior author; therefore, these taxa are of greater significance than the others. Full names of taxa are in figure 17 and table 4. 


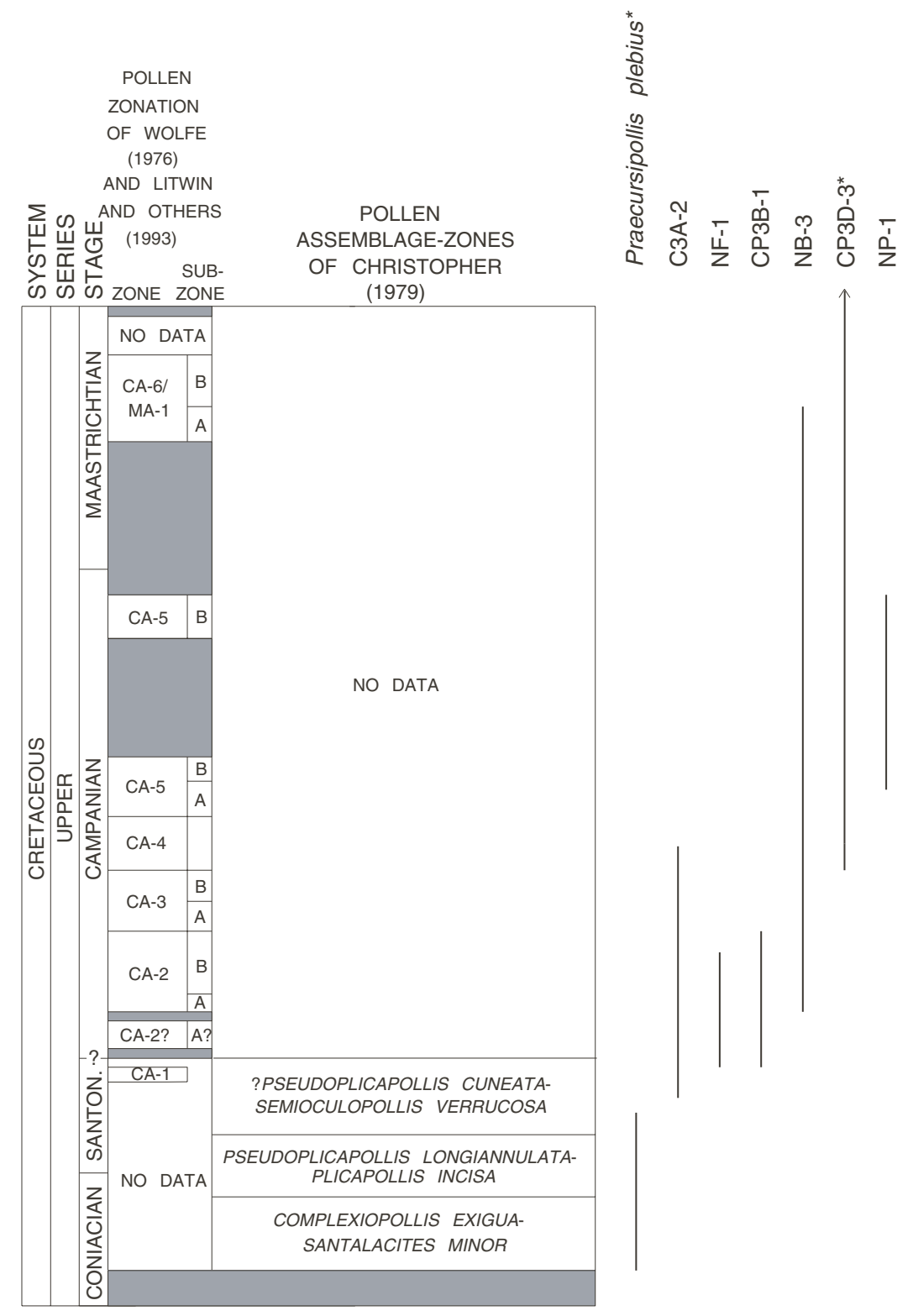

Figure 20. Chart showing known stratigraphic ranges of pollen taxa in sample R4581 I, Black Creek Group, from $517.0 \mathrm{ft}$ in the Millers Pond core, Burke County, Ga. The identification of taxa followed by an asterisk was checked by R.A. Christopher from photomicrographs provided by the senior author; therefore, these taxa are of greater significance than the others. Full names of taxa are in figure 17 and table 4. Trudopollis sp. cf. T. meekeri is not shown because the stratigraphic range of the species in the eastern United States is unknown. 


\section{SUMMARY}

Fifty-two Upper Cretaceous samples were examined for palynomorphs from four cores (Millhaven, Girard, Thompson Oak, and Millers Pond) in Screven and Burke Counties, Ga. (table 1). Seventeen of the samples from the Millhaven, Girard, and Millers Pond cores contained biostratigraphically useful angiosperm pollen assemblages.

Two pollen-bearing samples from the Cape Fear Formation were analyzed, both of them from the Millers Pond core. They are Coniacian or early Santonian, most probably Coniacian, in age.

The age of strata mapped as Middendorf Formation varies from place to place in the Carolinas (Christopher and others, 1997). For example, Gohn (1988, 1992), Clarke and others $(1994,1996)$, and Leeth and others (1996) showed this formation as being confined to the Santonian, whereas Lucas-Clark (1992, p. 81) considered the Middendorf to be "probably Santonian to Campanian in age." Christopher and others (1997) stated that at least some strata assigned to the Middendorf in the area of the Savannah River Site are the same age as the lowermost part of the Black Creek Group (which, according to the present paper, is probably at least in part mid-Campanian).

Three samples that contained angiosperm pollen were obtained from the Middendorf Formation in the present study. A sample from the Millhaven core (subunit 2) appears to be from Zone V of Coniacian and Santonian age. Two samples from the Girard core, from subunits 1 and 2, each contain a seemingly heterogeneous set of taxa whose known occurrences are Coniacian to Santonian, Campanian, or Maastrichtian. The peculiar nature of these two assemblages seems due to some combination of reworking, drilling mud contamination from uphole, species misidentification, and different species ranges in Georgia than in the Middle Atlantic States. However, at least the pollen flora of the sample from subunit 2 suggests a latest Santonian(?) or earliest Campanian age.

One sample from subunit 2 of the Middendorf Formation in the Millhaven core contained marginal marine or very nearshore marine dinoflagellates. Yet, five samples examined from the Middendorf of the Girard core contained pollen but lacked dinoflagellates and thus are probably nonmarine.

Seven pollen-bearing samples were examined in detail from the Black Creek Group, from the Millhaven, Girard, and Millers Pond cores. One sample from near the base of the Black Creek (subunit 1) in the Millhaven core has a pol- len assemblage probably assignable to mid-Campanian Zone CA-4 and has marginal marine or very nearshore dinoflagellates. Above this sample in the Millhaven core is a thick sequence of marine Black Creek sediments that contains late Campanian calcareous nannofossils of Zone CC 22 in subunit 2 (Bukry, this volume, chap. D) and abundant late Campanian marine dinoflagellates. Two pollen assemblages from subunit 2 and one from subunit 3 indicate poorly defined mid-Campanian to Maastrichtian ages. The lowest part of subunit 3 of the Black Creek Group in the Millhaven core has the same diverse late Campanian dinoflagellate assemblage as in subunit 2 of the core. However, the uppermost part of subunit 3 has a less diverse dinoflagellate assemblage, which indicates minor marine influence.

One sample from the Black Creek of the Girard core and two samples from the Black Creek of the Millers Pond core contained pollen grains. The Girard assemblage suggests a middle to late Campanian age; one Millers Pond assemblage gave only a poorly defined age, but the other assemblage seems to be mid-Campanian in age. In the Girard core, dinoflagellate presence and absence data indicate nonmarine conditions for subunit 1 and the lowermost part of subunit 2. The data indicate marine conditions for the remainder of subunit 2 and nonmarine conditions during deposition of subunit 3 of the Black Creek Group. The dinoflagellate taxa in subunit 2 indicate a late Campanian age.

Two samples of the Black Creek Group from the Thompson Oak core were examined for dinoflagellates. One sample contained sparse marine dinoflagellates indicating a late Campanian age, and the other lacked dinoflagellates.

Five pollen-bearing samples were analyzed from the Steel Creek Formation, all from the Millhaven core. All of these assemblages appear to be Maastrichtian in age. Two samples from the Steel Creek have dinoflagellates which, if indigenous and not representing contamination from uphole, indicate at least a marginally marine paleoenvironment. The Campanian-Maastrichtian boundary in the Millhaven core can be shown apparently to coincide with the contact between the Black Creek Group and the Steel Creek Formation by using a combination of pollen and dinoflagellate occurrence data.

All Cretaceous samples from the Millers Pond core lacked dinoflagellates. 


\section{REFERENCES CITED}

Aadland, R.K., 1992, Hydrogeologic characterization of the Cretaceous-Tertiary coastal plain sequence at Savannah River Site, South Carolina, in Zullo, V.A., Harris, W.B., and Price, Van, eds., Savannah River region; transition between the Gulf and Atlantic Coastal Plains: Proceedings of the Second Bald Head Island Conference on Coastal Plains Geology, Hilton Head Island, November 6-11, 1990, p. 62-67.

Aurisano, R.W., 1989, Upper Cretaceous dinoflagellate biostratigraphy of the subsurface Atlantic Coastal Plain of New Jersey and Delaware, U.S.A.: Palynology, v. 13, p. 143-179.

Burnett, J.A., 1996, Nannofossils and Upper Cretaceous (sub-) stage boundaries-State of the art: Journal of Nannoplankton Research, v. 18, no. 1, p. 23-32.

Christopher, R.A., 1977a, Selected Normapolles pollen genera and the age of the Raritan and Magothy Formations (Upper Cretaceous) of northern New Jersey, in Owens, J.P., Sohl, N.F., and Minard, J.P., eds., A field guide to Cretaceous and lower Tertiary beds of the Raritan and Salisbury embayments, New Jersey, Delaware, and Maryland: Guidebook prepared for the annual AAPG/SEPM convention, Washington, D.C., 1977, p. 58-69.

-1977b, The stratigraphic distribution of Normapolles and triporate pollen in Zones IV, V, and VII of the Raritan and Magothy Formations (Upper Cretaceous) of New Jersey [abs.]: American Association of Stratigraphic Palynologists, 10th Annual Meeting, Abstracts with Program, p. 7-8. Reprinted 1979 in Palynology, v. 3, p. 281.

1978, Quantitative palynologic correlation of three Campanian and Maestrichtian sections (Upper Cretaceous) from the Atlantic Coastal Plain: Palynology, v. 2, p. 1-27.

1979, Normapolles and triporate pollen assemblages from the Raritan and Magothy Formations (Upper Cretaceous) of New Jersey: Palynology, v. 3, p. 73-121, pls. 1-9.

1980, Cretaceous pollen, in Minard, J.P., Geology of the Round Bay quadrangle, Anne Arundel County, Maryland: U.S. Geological Survey Professional Paper 1109, p. 20-28.

1982a, Holkopollenites pollen "lineage" from the Upper Cretaceous Series of the Atlantic and Eastern Gulf Coastal Plain Province [abs.]: Palynology, v. 6, p. 275-276.

-1982b, Palynostratigraphy of the basal Cretaceous units of the eastern Gulf and southern Atlantic Coastal Plains, in Arden, D.D., Beck, B.F., and Morrow, Eleanore, eds., Proceedings; second symposium on the geology of the southeastern coastal plain: Georgia Geologic Survey Information Circular 53, p. 10-23, pls. 1-3.

1982c, The occurrence of the Complexiopollis-Atlantopollis Zone (palynomorphs) in the Eagle Ford Group (Upper Cretaceous) of Texas: Journal of Paleontology, v. 56, no. 2, p. 525-541, 1 pl.

Christopher, R.A., Owens, J.P., and Sohl, N.F., 1979, Late Cretaceous palynomorphs from the Cape Fear Formation of North Carolina: Southeastern Geology, v. 20, no. 3, p. 145-159.

Christopher, R.A., Prowell, D.C., and Gohn, G.S., 1997, Questions regarding the stratigraphic relationship between the Cape Fear and Middendorf Formations [abs.]: Fifth Annual Clemson University Hydrogeology Symposium, Abstracts, no pagination.
Clarke, J.S., 1993, Conceptual models of possible stream-aquifer relations in the vicinity of the Savannah River Site, Georgia and South Carolina [abs.]: Geological Society of America Abstracts with Programs, v. 25, no. 4, p. 8.

Clarke, J.S., Falls, W.F., Edwards, L.E., [Bukry, David,] Frederiksen, N.O., Bybell, L.M., Gibson, T.G., Gohn, G.S., and Fleming, Farley, 1996, Hydrogeologic data and aquifer interconnection in a multi-aquifer system in coastal plain sediments near Millhaven, Screven County, Georgia, 1991-95: Georgia Geologic Survey Information Circular 99, 43 p., 1 pl. in pocket.

Clarke, J.S., Falls, W.F., Edwards, L.E., Frederiksen, N.O., Bybell, L.M., Gibson, T.G., and Litwin, R.J., 1994 [1995], Geologic, hydrologic and water-quality data for a multi-aquifer system in coastal plain sediments near Millers Pond, Burke County, Georgia, 1992-93: Georgia Geologic Survey Information Circular 96, 34 p., 1 pl. in pocket.

Clarke, J.S., and West, C.T., 1994, Development of water-table and potentiometric-surface maps for coastal plain aquifers in the vicinity of the Savannah River Site, South Carolina and Georgia [abs.]: Geological Society of America Abstracts with Programs, v. 26 , no. 4 , p. 8.

Doyle, J.A., 1969, Cretaceous angiosperm pollen of the Atlantic Coastal Plain and its evolutionary significance: Journal of the Arnold Arboretum, v. 50, p. 1-35.

Doyle, J.A., and Robbins, E.I., 1977, Angiosperm pollen zonation of the continental Cretaceous of the Atlantic Coastal Plain and its application to deep wells in the Salisbury Embayment: Palynology, v. 1, p. 43-78.

Edwards, L.E., 1992, Dinocysts from the lower Tertiary units in the Savannah River area, South Carolina and Georgia, in Zullo, V.A., Harris, W.B., and Price, Van, eds., Savannah River region; transition between the Gulf and Atlantic Coastal Plains: Proceedings of the Second Bald Head Island Conference on Coastal Plains Geology, Hilton Head Island, November 6-11, 1990, p. 97-99.

Edwards, L.E., and Clarke, J.S., 1992, Biostratigraphic investigations help evaluation of the ground-water-flow system near the Savannah River Site, Georgia and South Carolina [abs.], in Proceedings, Fifth North American Paleontological Convention, Chicago, Ill., June 28-July 1, 1992: Paleontological Society Special Publication 6, p. 90.

Edwards, L.E., and Frederiksen, N.O., 1992, Paleogene palynomorph correlations in eastern Georgia [abs.]: Geological Society of America Abstracts with Programs, v. 24, no. 2, p. 14.

Edwards, L.E., Frederiksen, N.O., Bybell, L.M., Gohn, G.S., Self-Trail, J.M., Gibson, T.G., Bukry, David, and Fleming, R.F., 1997, Mysteries solved in the stratigraphy of the updip coastal plain of Georgia [abs.]: Fifth Annual Clemson University Hydrogeology Symposium, Abstracts, no pagination.

Falls, W.F., Baum, J.S., and Prowell, D.C., 1997, Physical stratigraphy and hydrostratigraphy of Upper Cretaceous and Paleocene sediments, Burke and Screven Counties, Georgia: Southeastern Geology, v. 36, p. 153-176.

Falls, W.F., Prowell, D.C., Edwards, L.E., Frederiksen, N.O., Gibson, T.G., Bybell, L.M., and Gohn, G.S., 1993, Preliminary correlation of geologic units in three coreholes along the Savannah River in Burke and Screven Counties, Georgia 
[abs.]: Geological Society of America Abstracts with Programs, v. 25 , no. 4 , p. 14.

Firth, J.V., 1987, Dinoflagellate biostratigraphy of the Maastrichtian to Danian interval in the U.S. Geological Survey Albany core, Georgia, U.S.A.: Palynology, v. 11, p. 199-216.

Frederiksen, N.O., 1979, Paleogene sporomorph biostratigraphy, northeastern Virginia: Palynology, v. 3, p. 129-167.

Frederiksen, N.O., and Christopher, R.A., 1978, Taxonomy and biostratigraphy of Late Cretaceous and Paleogene triatriate pollen from South Carolina: Palynology, v. 2, p. 113-145.

Gellici, J.A., and Logan, W.R., 1993, Preliminary stratigraphic and hydrostratigraphic correlation of four deep coreholes east of the Savannah River Site in Allendale, Barnwell and Aiken Counties, South Carolina [abs.]: Geological Society of America Abstracts with Programs, v. 25, no. 4, p. 17.

Gohn, G.S., 1988, Late Mesozoic and early Cenozoic geology of the Atlantic Coastal Plain: North Carolina to Florida, in Sheridan, R.E., and Grow, J.A., eds., The Atlantic continental margin; U.S., v. I-2 of Geology of North America: Boulder, Colo., Geological Society of America, p. 107-130.

1992, Revised nomenclature, definitions, and correlations for the Cretaceous formations in USGS-Clubhouse Crossroads \#1, Dorchester County, South Carolina: U.S. Geological Survey Professional Paper 1518, 39 p., 1 pl. in pocket.

Gray, T.C., and Groot, J.J., 1966, Pollen and spores from the marine Upper Cretaceous formations of Delaware and New Jersey: Palaeontographica, ser. B, v. 117, p. 114-134.

Habib, Daniel, and Miller, J.A., 1989, Dinoflagellate species and organic facies evidence of marine transgression and regression in the Atlantic Coastal Plain: Palaeogeography, Palaeoclimatology, Palaeoecology, v. 74, p. 23-47.

Habib, Daniel, Olsson, R.K., Liu, Chengjie, and Moshkovitz, Shimon, 1996, High-resolution biostratigraphy of sea-level low, biotic extinction, and chaotic sedimentation at the Cretaceous-Tertiary boundary in Alabama, north of the Chicxulub crater, in Ryder, G., Fastovsky, D., and Gartner, S., eds., The Cretaceous-Tertiary event and other catastrophes in Earth history: Geological Society of America Special Paper 307, p. 243-252.

Harris, M.K., Aadland, R.K., and Westbrook, T.M., 1992, Lithological and hydrological characteristics of the Tertiary hydrostratigraphic systems of the General Separations Area, Savannah River Site, South Carolina, in Zullo, V.A., Harris, W.B., and Price, Van, eds., Savannah River region; transition between the Gulf and Atlantic Coastal Plains: Proceedings of the Second Bald Head Island Conference on Coastal Plains Geology, Hilton Head Island, November 6-11, 1990, p. 6873.

Koch, R.C., and Olsson, R.K., 1977, Dinoflagellate and planktonic foraminiferal biostratigraphy of the uppermost Cretaceous of New Jersey: Journal of Paleontology, v. 51, p. 480-491.

Leeth, D.C., Falls, W.F., Edwards, L.E., Frederiksen, N.O., and Fleming, R.F., 1996, Geologic, hydrologic, and water-chemistry data for a multi-aquifer system in coastal plain sediments near Girard, Burke County, Georgia, 1992-95: Georgia Geologic Survey Information Circular 100, 26 p., 1 pl.

Litwin, R.J., Sohl, N.F., Owens, J.P., and Sugarman, P.J., 1993, Palynological analysis of a newly recognized Upper Cretaceous marine unit at Cheesequake, New Jersey: Palynology, v. 17 , p. 123-135, pls. $1-3$.
Lucas-Clark, Joyce, 1992, Problems in Cretaceous palynostratigraphy (dinoflagellates and pollen) of the Savannah River Site area, in Zullo, V.A., Harris, W.B., and Price, Van, eds., Savannah River region; transition between the Gulf and Atlantic Coastal Plains: Proceedings of the Second Bald Head Island Conference on Coastal Plains Geology, Hilton Head Island, November 6-11, 1990, p. 81-82.

May, F.E., 1980, Dinoflagellate cysts of the Gymnodiniaceae, Peridiniaceae, and Gonyaulacaceae from the Upper Cretaceous Monmouth Group, Atlantic Highlands, New Jersey: Palaeontographica, ser. B, v. 172, p. 10-116.

Olsson, R.K., Gibson, T.G., Hansen, H.J., and Owens, J.P., 1988, Geology of the northern Atlantic coastal plain: Long Island to Virginia, in Sheridan, R.E., and Grow, J.A., eds., The Atlantic continental margin; U.S, v. I-2 of Geology of North America: Boulder, Colo., Geological Society of America, p. 87-105.

Perch-Nielsen, Katharina, 1985, Mesozoic calcareous nannofossils, in Bolli, H.M., Saunders, J.B., and Perch-Nielsen, Katharina, eds., Plankton stratigraphy: New York, Cambridge University Press, p. 329-426.

Prowell, D.C., Christopher, R.A., Edwards, L.E., Bybell, L.M., and Gill, H.E., 1985 [1986], Geologic section of the updip coastal plain from central Georgia to western South Carolina: U.S. Geological Survey Miscellaneous Field Studies Map MF1737, 10-p. text, 1 sheet.

Prowell, D.C., Edwards, L.E., and Frederiksen, N.O., 1985 [1986], The Ellenton Formation in South Carolina-A revised age designation from Cretaceous to Paleocene, in Stratigraphic notes, 1984: U.S. Geological Survey Bulletin 1605-A, p. A63-A69.

Self-Trail, J.M., and Bybell, L.M., 1995, Cretaceous and Paleogene calcareous nannofossil biostratigraphy of New Jersey, in Baker, J.E.B., ed., Contributions to the paleontology of New Jersey: Geological Association of New Jersey Contribution Proceedings, v. 12, p. 102-139.

Sirkin, L.A., 1974, Palynology and stratigraphy of Cretaceous strata in Long Island, N.Y., and Block Island, Rhode Island: U.S. Geological Survey Journal of Research, v. 2, p. 431-440.

Sohl, N.F., Martínez R., Eduardo, Salmerón-Ureña, Pedro, and Soto-Jaramillo, Fidel, 1991, Upper Cretaceous, in Salvador, Amos, ed., The Gulf of Mexico Basin, v. J of Geology of North America: Boulder, Colo., Geological Society of America, p. 205-244.

Srivastava, S.K., 1991, Cenomanian-Coniacian dinocysts from the western Gulf Coastal Plain, southern United States: Palaeobotanist, v. 39, no. 2, p. 155-235.

1993, Dinocyst biostratigraphy of Santonian-Maastrichtian formations of the western Gulf Coastal Plain, southern United States: Palaeobotanist, v. 42, no. 3, p. 249-362.

Stover, L.E., Elsik, W.C., and Fairchild, W.W., 1966, New genera and species of early Tertiary palynomorphs from Gulf Coast: Kansas University Paleontological Contributions, Paper 5, 10 p.

Strom, R.N., Kaback, D.S., and Schramke, J.A., 1992, Groundwater geochemistry and flow path modeling, Savannah River Site, S.C. [abs.]: Geological Society of America Abstracts with Programs, v. 24, no. 2, p. 69.

Sugarman, P.J., Miller, K.G., Bukry, David, and Feigenson, M.D., 1995, Uppermost Campanian-Maestrichtian strontium isotopic, biostratigraphic, and sequence stratigraphic framework of 
the New Jersey Coastal Plain: Geological Society of America Bulletin, v. 107, p. 19-37.

Thomson, P.W., and Pflug, H.D., 1953, Pollen und Sporen des mitteleuropäischen Tertiärs: Palaeontographica, ser. B, v. 94, 138 p.

Tschudy, R.H., 1970, Two new pollen genera (Late Cretaceous and Paleocene) with possible affinity to the Illiciaceae: U.S. Geological Survey Professional Paper 643-F, p. F1-F13.

1973, Complexiopollis pollen lineage in Mississippi embayment rocks: U.S. Geological Survey Professional Paper 743-C, 15 p.

1975, Normapolles pollen from the Mississippi embayment: U.S. Geological Survey Professional Paper 865, 42 p.
Whitney, B.L., 1979, A population study of Alterbia acutula (Wilson) Lentin \& Williams from the Maestrichtian (Upper Cretaceous) of Maryland: Palynology, v. 3, p. 123-128.

Wolfe, J.A., 1976, Stratigraphic distribution of some pollen types from the Campanian and lower Maestrichtian rocks (Upper Cretaceous) of the Middle Atlantic States: U.S. Geological Survey Professional Paper 977, 18 p., 4 pls.

Zaitzeff, J.B., and Cross, A.T., 1971, The use of dinoflagellates and acritarchs for zonation and correlation of the Navarro Group (Maastrichtian) of Texas: Geological Society of America Special Paper 127, p. 341-377. 